\title{
Phytoplankton temporal dynamics in the coastal waters of the north-eastern Adriatic Sea (Mediterranean Sea) from 2010 to 2017
}

\author{
Federica Cerino', Daniela Fornasaro', Martina Kralj', Michele Giani', \\ Marina Cabrini ${ }^{\prime}$
}

I Oceanography Section, Istituto Nazionale di Oceanografia e di Geofisica Sperimentale - OGS, Via A. Piccard 54, 34151 Trieste, Italy

Corresponding author: Federica Cerino (fcerino@inogs.it)

Academic editor: A. Lugliè | Received 20 October 2018 | Accepted Accepted 6 February 2019 | Published 3 May 2019

http://zoobank.org/8B70359F-B283-4FFD-84EE-28371EC70EFE

Citation: Cerino F, Fornasaro D, Kralj M, Giani M, Cabrini M (2019) Phytoplankton temporal dynamics in the coastal waters of the north-eastern Adriatic Sea (Mediterranean Sea) from 2010 to 2017. In: Mazzocchi MG, Capotondi L, Freppaz M, Lugliè A, Campanaro A (Eds) Italian Long-Term Ecological Research for understanding ecosystem diversity and functioning. Case studies from aquatic, terrestrial and transitional domains. Nature Conservation 34: $343-372$. https://doi.org/10.3897/natureconservation.34.30720

\begin{abstract}
Phytoplankton community structure was analysed from 2010 to 2017 at C1-LTER, the coastal LongTerm Ecological Research station located in the Gulf of Trieste, which is the northernmost part of the Mediterranean Sea. Phytoplankton abundance and relevant oceanographic parameters were measured monthly in order to describe the seasonal cycle and interannual variability of the main phytoplankton taxa (diatoms, dinoflagellates, coccolithophores and flagellates) and to analyse their relationship with environmental conditions. Overall, phytoplankton abundances showed a marked seasonal cycle characterised by a bloom in spring, with the peak in May. During the summer, phytoplankton abundances gradually decreased until September, then slightly increased again in October and reached their minima in winter. In general, the phytoplankton community was dominated by flagellates (generally $<10 \mu \mathrm{m}$ ) and diatoms co-occurring in the spring bloom. In this period, diatoms were also represented by nano-sized species, gradually replaced by larger species in summer and autumn. Phytoplankton assemblages differed significantly between seasons (Pseudo-F $=9.59 ; p<0.01$ ) and temperature and salinity were the best predictor variables explaining the distribution of the multivariate data cloud. At the interannual scale, a strong decrease of the late-winter bloom was observed in recent years with the spring bloom being the main phytoplankton increase of the year.
\end{abstract}

Copyright Federica Cerino et al. This is an open access article distributed under the terms of the Creative Commons Attribution License (CC BY 4.0), which permits unrestricted use, distribution, and reproduction in any medium, provided the original author and source are credited. 


\section{Keywords}

Phytoplankton diversity, interannual variability, seasonality, Long-Term Ecological Research, Adriatic Sea, nutrients

\section{Introduction}

Marine ecosystems are experiencing many different changes in response to natural processes, human activities and climate change. These changes are rapidly altering nearly every chemical, physical and biological property affecting the growth of marine microorganisms (Hutchins and $\mathrm{Fu}$ 2017). Phytoplankton are a key component of marine ecosystem dynamics, contributing about half the global net primary production (Field et al. 1998). They represent the base of the food web and play a pivotal role in global nutrient cycles and particle export to the bottom. As primary producers, they are directly dependent on abiotic variables and are very sensitive to environmental changes of which they are actually important indicators (Hays et al. 2005). Therefore, tracking changes in the phytoplankton community structure can help to forecast ecosystem changes and plan sustainable management of the seas and oceans. For this reason, for instance, phytoplankton community diversity and temporal modification have been included as useful indicators in the Marine Strategy Framework Directive (MSFD) to determine the achievement of Good Environmental Status for the protection and conservation of the marine ecosystem. However, to disentangle climate and anthropogenic pressures from natural variability, many years of observations are needed (Henson et al. 2010) and, with this in mind, long-term data offer a useful instrument for achieving this aim and improving decision-making in ocean and coastal management (Edwards et al. 2010). Several marine research institutes maintain time series of physical, chemical and biological parameters for over a decade and are referred to as Long-Term Ecological Research sites (LTER). In Italy, the Italian Long-Term Ecological Research Network (LTER-Italy) includes terrestrial, freshwater and marine sites where observations are carried out at multidecadal scale. This study is based on data collected at the station C1-LTER that, since 2006, has been formally included in the LTER-Italy as part of the northern Adriatic LTER site.

The analyses of time series available for the northern Adriatic LTER site have highlighted that the northern Adriatic has experienced significant modifications of environmental conditions and trophic structure (Giani et al. 2012). The authors suggested that these changes were probably indicative of gradual eutrophication that occurred in the period from 1970 to mid-1980, followed by an oligotrophication process in the period 2000-2007, and drew attention to the possible effects on fish productivity. Phytoplankton interannual and inter-decadal variability, as well as temporal trends, have been reported for the northern Adriatic (Ninčević Gladan et al. 2010; Mozetić et al. 2010; Bernardi Aubry et al. 2012; Cabrini et al. 2012; Marić et al. 2012; Mozetić et al. 2012). An analysis encompassing 38 years (1970-2007) showed a strong decrease of chlorophyll a concentration in the whole northern basin probably due to a reduction of freshwater discharges and phosphorus used in agriculture (Mozetić et al. 2010). A recent analysis 
carried out in the Mediterranean Sea, encompassing more recent years (1998-2014) and based on satellite-derived chlorophyll concentration, found a positive trend of chlorophyll concentration in the northern Adriatic Sea (Salgado-Hernanz et al. 2019). Different regime shifts have also been reported for phytoplankton abundances, community composition and seasonal cycle (Cabrini et al. 2012; Marić et al. 2012; Mozetić et al. 2012). At the C1-LTER station in the Gulf of Trieste, Cabrini et al. (2012) analysed a long-term dataset (1986-2010) and reported a regime shift of phytoplankton abundances in 1994, but no relationship with environmental forcing was presented.

The aim of this study is to analyse the temporal dynamics of the phytoplankton community at a seasonal and interannual scale during the past eight years (2010 2017 ) in the coastal waters and infer the possible environmental drivers shaping the variability of phytoplankton assemblages.

\section{Methods}

\section{Study area}

The Gulf of Trieste is a semi-enclosed basin located in the north-western part of the Adriatic Sea, characterised by shallow depths (maximum $25 \mathrm{~m}$ ) and a strong influence of freshwater inputs. Two main rivers, the Isonzo and Timavo Rivers, enter the gulf along the shallower north-west coastline, whereas several submarine freshwater springs flow along the eastern karstic coast. The Isonzo River is the major source of freshwater and nutrients in the gulf and deeply modulates the hydrology, biogeochemistry and productivity of this coastal area (Cozzi et al. 2012). The oceanographic properties of the gulf are highly variable due to a marked seasonal cycle of seawater temperature (from winter minima of $5^{\circ} \mathrm{C}$ to summer maxima $\left.>26^{\circ} \mathrm{C}\right)$ and strong salinity gradients $(25-$ 38) (Malačić and Petelin 2001). The overall circulation is mostly cyclonic and mainly influenced by the Eastern Adriatic Current, flowing northwards along the eastern coast and advecting warmer, saltier and more oligotrophic waters coming from the Ionian Sea (Poulain and Cushman-Roisin 2001), and by winds typical of the area, the cold Bora wind from the east-north and mild Scirocco wind from the south (Querin et al. 2007).

\section{Sampling and environmental parameters}

Data considered in this paper were collected at the C1-LTER station $\left(45^{\circ} 42^{\prime} 2.99^{\prime \prime} \mathrm{N}\right.$ and 13 $42^{\prime} 36.00^{\prime \prime E}$, bottom depth: $17 \mathrm{~m}$ ) located in the Gulf of Trieste. C1-LTER, $270 \mathrm{~m}$ far from the coast, north of the town of Trieste (Fig. 1), is part of the LTER network (http://www.lteritalia.it/) since 2006 and is sampled monthly since 1986 (http:// nettuno.ogs.trieste.it/ilter/BIO/history.html). Data presented here cover a period of eight years for a total of 384 samples collected monthly from January 2010 to December 2017 at four depths $(0.5,5,10$ and $15 \mathrm{~m})$ by $5 \mathrm{~L}$ Niskin bottles. 


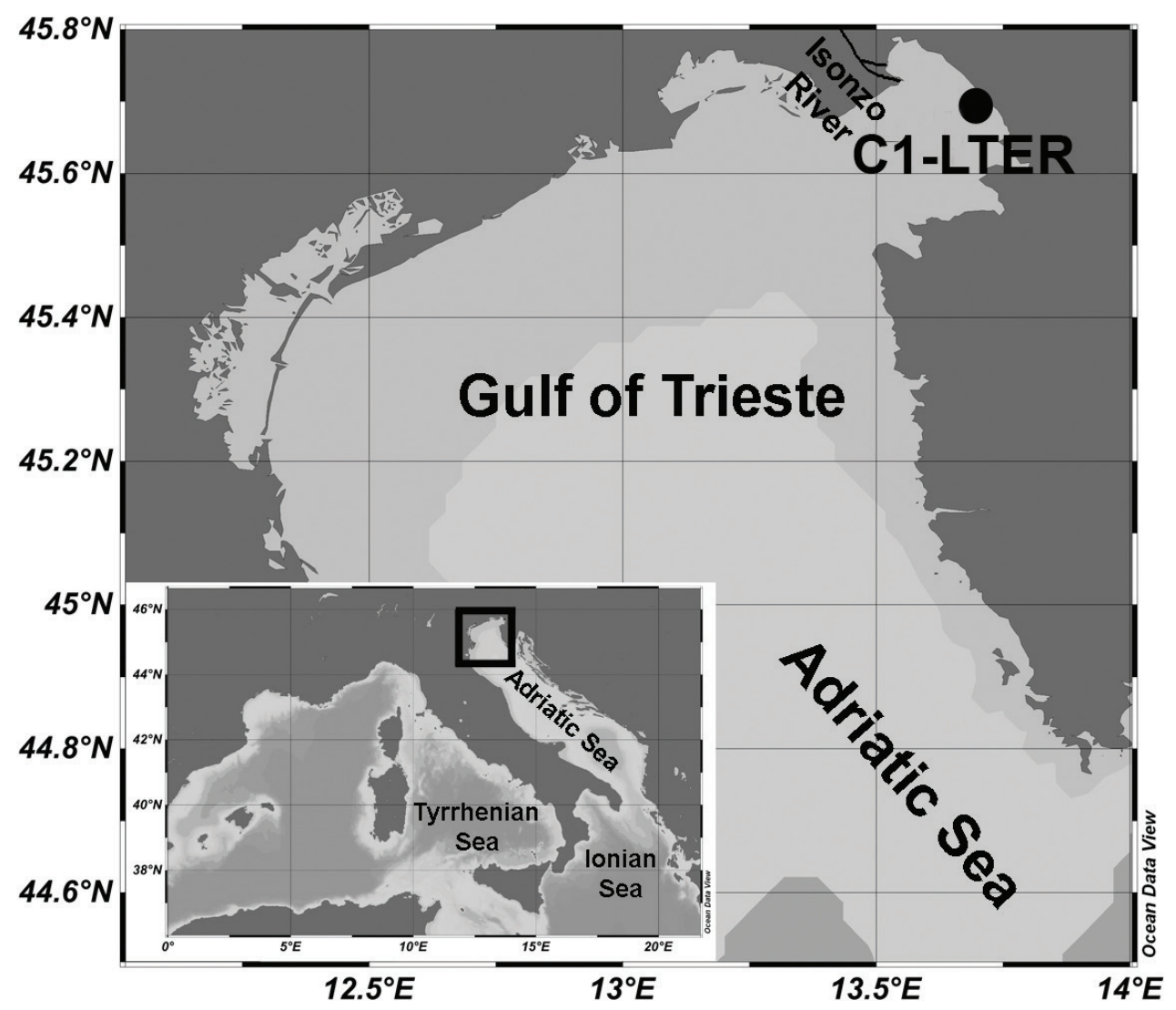

Figure I. Map of the study area in the northern Adriatic Sea (Mediterranean Sea) showing the location of the sampling station (C1-LTER).

CTD profiles of temperature and salinity were obtained with an Idronaut Ocean Seven (models 401 and 316) or SBE 19plus SEACAT multiparametric probe, calibrated every $6 / 12$ months.

Total precipitations data, provided by ARPA FVG - OSMER e GRN, Trieste (http://www.meteo.fvg.it/), were registered at the station situated at Molo Fratelli Bandiera (453' $\left.59.99^{\circ} \mathrm{N}, 13^{\circ} 45^{\prime} 8.07^{\prime \prime} \mathrm{E}\right)$.

The Isonzo River discharge data, provided by Regione Autonoma Friuli Venezia Giulia, were calculated by a rating curve from the hydrometric level registered at Turriaco station (13 km from the Isonzo River mouth).

Samples for the determination of dissolved inorganic nutrient (nitrite, $\mathrm{N}-\mathrm{NO}_{2}$, nitrate, $\mathrm{N}-\mathrm{NO}_{3}$, ammonia, $\mathrm{N}-\mathrm{NH}_{4}$, phosphate, $\mathrm{P}_{-} \mathrm{PO}_{4}$, and silicate, $\left.\mathrm{Si}-\mathrm{Si}(\mathrm{OH})_{4}\right)$ concentrations were pre-filtered through precombusted size glass-fibre filters (Whatmann $\mathrm{GF} / \mathrm{F}$ ), stored at $-20^{\circ} \mathrm{C}$ and then analysed colorimetrically with a Bran + Luebbe Autoanalyzer 3, up to December 2013, and afterwards with a QuAAtro (Seal Analytical), according to Hansen and Koroleff (1999). The concentration of dissolved inorganic 
nitrogen (DIN) was calculated as the sum of the concentrations of nitrite, nitrate and ammonia. The detection limits for DIN, phosphates and silicates were $0.02,0.01$ and $0.01 \mu \mathrm{mol} \mathrm{L}{ }^{-1}$, respectively.

Temperature and salinity profiles and nutrient concentrations were plotted using Ocean Data View ver. 4.7.10 (Schlitzer 2015).

\section{Phytoplankton abundance}

For phytoplankton analysis, samples were fixed with pre-filtered and neutralised formaldehyde (1.6\% final concentration) (Throndsen 1978). A variable volume of seawater $(10-50 \mathrm{~mL})$ was settled in an Utermöhl chamber depending on cell abundance (Utermöhl 1958; Zingone et al. 2010). Cell counts were performed using an inverted light microscope (LM) (Olympus IX71 and LEICA BMI3000B) equipped with phase contrast. Cells (minimum 200) were counted along transects (1-2) at a magnification of 400x. Additionally, half of the sedimentation chamber was also examined at a magnification of $200 \times$ for a more precise identification of less abundant microphytoplankton $(>20 \mu \mathrm{m})$ taxa. Phytoplankton specimens were identified to the lowest possible taxonomic level and species/genus names were checked for validity against AlgaeBase (Guiry and Guiry 2018), and relevant recent publications. Heterotrophic species of some dinoflagellate and nanoflagellate genera, and of the protozoan class Cercozoa, were also included since they are usually considered in phytoplankton studies. Identified taxa were reported per major groups such as diatoms, dinoflagellates, coccolithophores and flagellates, the latter including several phytoplankton classes (mostly smaller than $10 \mu \mathrm{m}$ forms of uncertain taxonomic identification under LM afterwards named nanoflagellates, chryso-, chloro-, crypto-, dictyocho-, eugleno-, prasino-, primnesiophytes, ebridea, choanoflagellates and incertae sedis). With 'total phytoplankton', through the manuscript, it is intended all species/taxa detectable in light microscopy; therefore, prokaryotic phytoplankton and the majority of picoeukaryotes $(<1 \mu \mathrm{m})$ were not considered.

\section{Statistical analyses}

The distributions of nutrient concentrations and main phytoplankton group abundances were checked for significant differences among seasons, years, months and depths through analysis of variance (Kruskal-Wallis ANOVA). When significant differences were observed $(p<0.05)$, post hoc comparisons of mean ranks of all pairs of groups (Siegel and Castellan 1998) were also performed to further assess these statistically significant differences.

A non-parametric Spearman rank order correlation was used to assess the relationship in surface waters among oceanographic parameters (temperature, salinity, DIN, $\mathrm{P}_{-} \mathrm{PO}_{4}$ and $\mathrm{Si}-\mathrm{Si}(\mathrm{OH})_{4}$ ), total precipitations on the three days preceding sampling, Isonzo River discharge on the day preceding sampling, considering the dataset grouped 
per season. Additionally, the influence of environmental variables (temperature, salinity, DIN, $\mathrm{P}-\mathrm{PO}_{4}$ and $\left.\mathrm{Si}-\mathrm{Si}(\mathrm{OH})_{4}\right)$ on the phytoplankton groups and taxa was considered using the water column integrated values. These analyses were performed using the Statistica 7.0 software package (StatSoft).

A reduced taxa dataset ( 85 taxa) was used to calculate the Indicator Value Index (Ind $\mathrm{Val}$ ) and to perform multivariate statistical analyses: from the whole dataset comprising 122 taxa, any taxa with a lower than 10\% frequency percentage were eliminated and species abundances were integrated on four depths using the trapezoidal method. The trapezoidal rule works by approximating the region under the graph of the function as a trapezoid and calculating its area.

Before performing the multivariate analyses, the species abundance values were $\log (\mathrm{X}+1)$ transformed to diminish the effect of the most abundant species, and the dissimilarity matrix was computed based on the Bray-Curtis index. The environmental variables (temperature, salinity, total precipitations, Isonzo River discharge and nutrient concentrations) were first tested for multi-collinearity and symmetric distribution using PRIMER's Draftsman Plot tool and then normalised. The dissimilarity matrix was calculated based on the Euclidean distance.

To assess differences in species composition among seasons, a PERMANOVA test was applied considering the 'season' as a fixed factor. Unrestricted permutations of row data and 999 permutations were performed.

The effect of abiotic variables (temperature, salinity, total precipitations, Isonzo River discharge, dissolved inorganic nitrogen, phosphates and silicates) on the phytoplankton community was assessed by distance-based redundancy analysis (dbRDA, Legendre and Anderson 1999) that produced a better model of the relationship between the multivariate data cloud and environmental variables.

All these analyses were performed using the PRIMER software package (v. 7), including the add-on PERMANOVA+ package.

To assess species characterising seasons (winter: January, February and March; spring: April, May and June; summer: July, August and September; autumn: October, November and December), the IndVal (Dufrêne and Legendre 1997) was applied, grouping all samples per season. The indicator considers both the specificity and the fidelity, namely whether a species is abundant in a specific type of habitat and predominantly found in this type of habitat, respectively. The analysis was performed using the labdsv package in the $\mathrm{R}$ program (v. 3.3.0).

\section{Results}

\section{Seasonal cycle and interannual variability of oceanographic parameters and fresh- water inputs}

The seasonal cycle and interannual variability of oceanographic parameters are showed in Figures 2, 3. Water temperature showed a marked seasonal cycle (Fig. 2A) with winter minima and summer maxima. In general, late autumn and winter were character- 

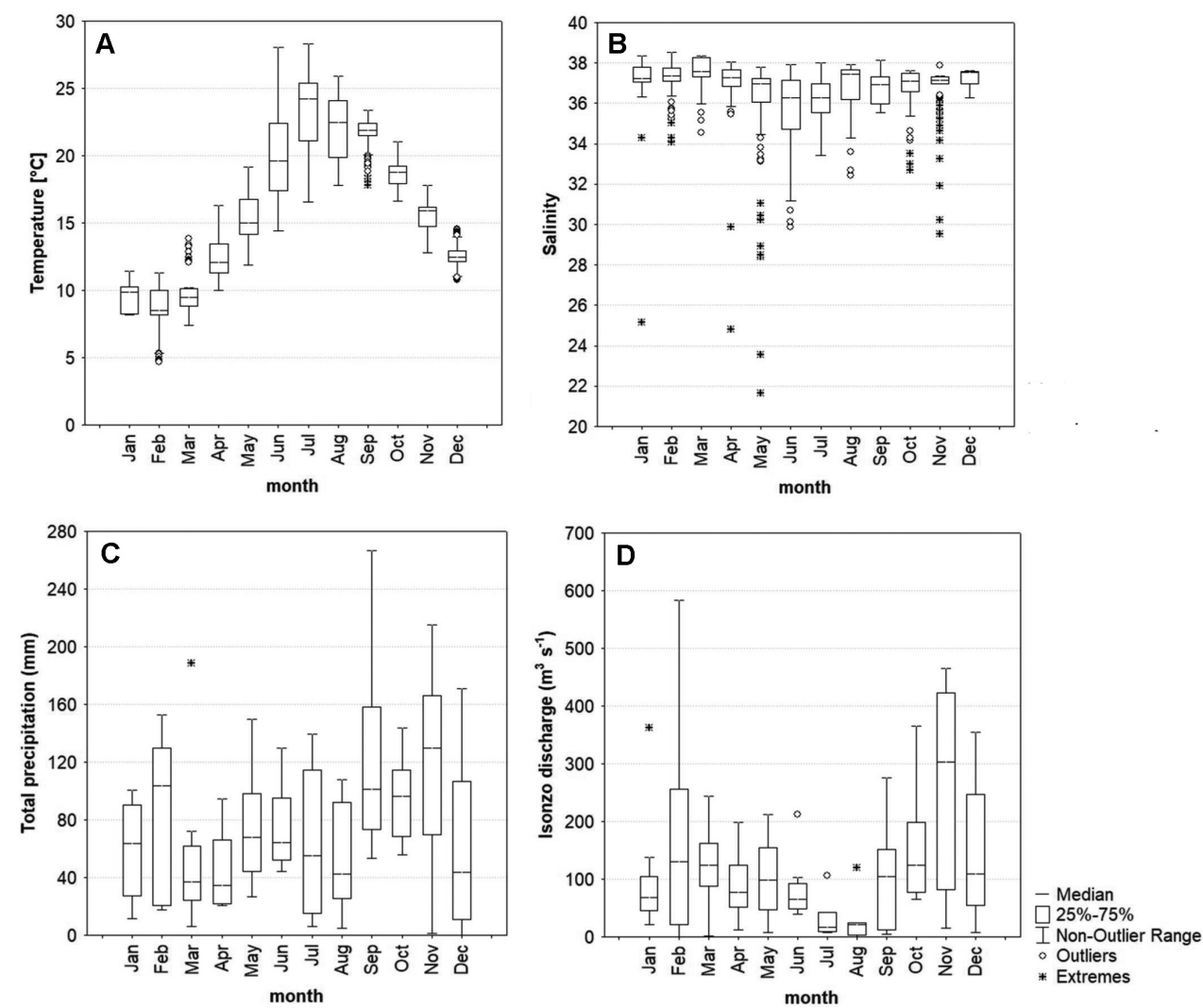

Figure 2. Seasonal cycles of temperature profiles $(\mathbf{A})$, salinity profiles $(\mathbf{B})$, precipitations $(\mathbf{C})$ and Isonzo River discharge (D). In the box plot, the bold line represents the median, the box the $25^{\text {th }}$ and $75^{\text {th }}$ percentiles of the distribution, the whisker the non-outlier range, the circle the outliers and the star the extremes.

ised by vertical mixing of the water column, while the thermal stratification started in April-May and became more pronounced in June-August (Fig. 3A). After winter cooling, water temperature increased until July, which was on average the hottest month, with the highest value of $28.34^{\circ} \mathrm{C}$ recorded in 2015 at the surface, and then decreased through the autumn months (Fig. 2A). During the first three years, seawater temperature was particularly low in winter (medians along the water column, 9.01, 8.61 and $7.57^{\circ} \mathrm{C}$ in 2010, 2011 and 2012, respectively), with the lowest value of $4.71{ }^{\circ} \mathrm{C}$ in February 2012 at the bottom. In the successive winters, 2013-2016, seawater temperature was higher (medians along the water column ranged from 9.44 to $11.34^{\circ} \mathrm{C}$ ). The winter of 2017 was colder again (median $8.51^{\circ} \mathrm{C}$ ).

The salinity also showed a clear seasonality with the minimum recorded in spring and the maximum in winter (Fig. 2B). Generally, salinity values ranged from 34.00 to 38.50; however, low values $(<30)$ were occasionally detected at the surface: in May, June and November 2010 (21.66, 29.86 and 29.52, respectively), April 2013 (24.83), January 2014 (25.14), and May 2016 (28.51). 

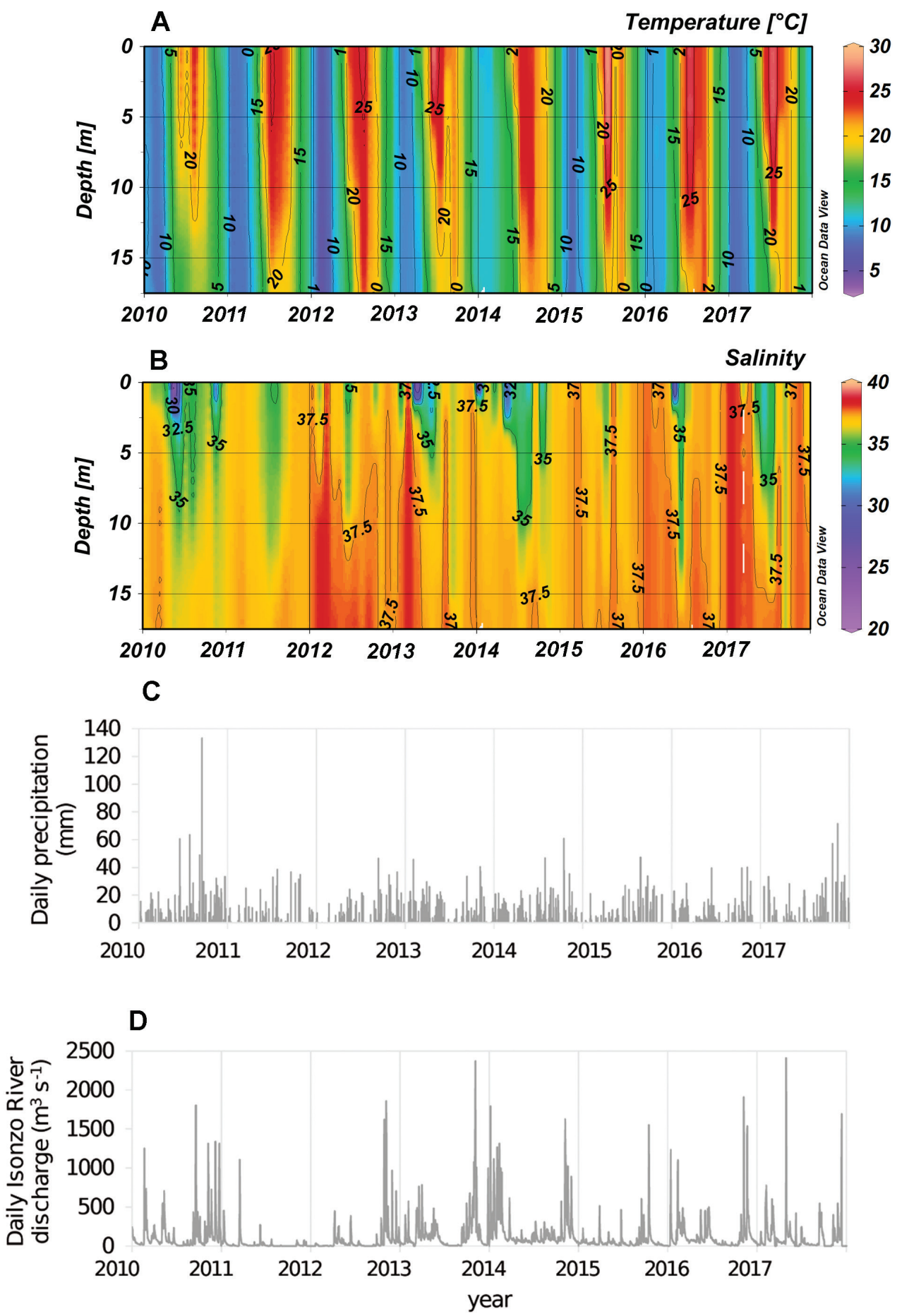

Figure 3. Interannual distributions of temperature profiles $(\mathbf{A})$, salinity profiles $(\mathbf{B})$, precipitations $(\mathbf{C})$ and Isonzo River discharge (D). 

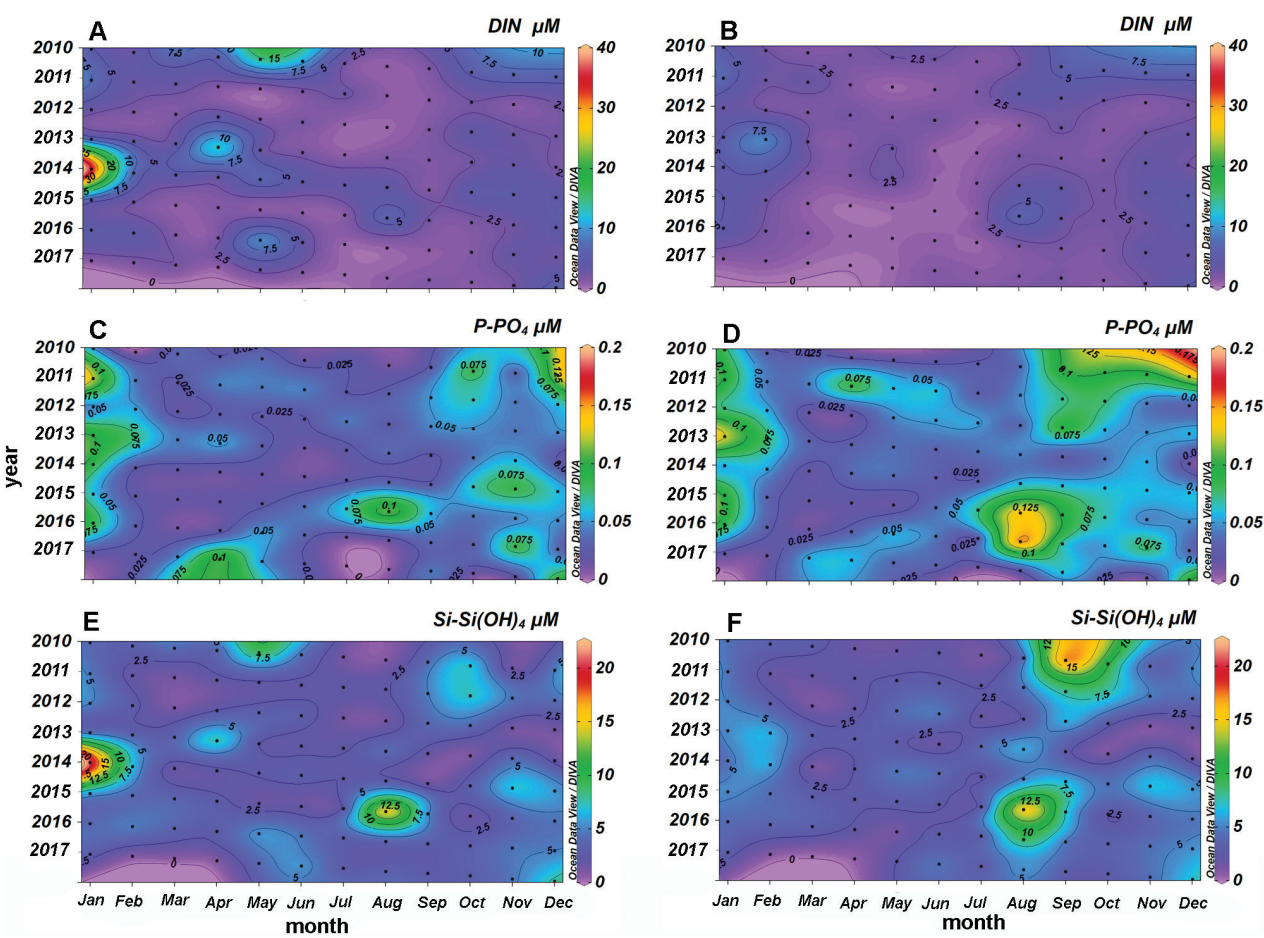

Figure 4. Seasonal and interannual distribution of dissolved inorganic nitrogen (DIN) (A-B), phosphate $\left(\mathrm{P}-\mathrm{PO}_{4}\right)(\mathbf{C}-\mathbf{D})$ and silicate $\left(\mathrm{Si}-\mathrm{Si}(\mathrm{OH})_{4}\right)(\mathbf{E}-\mathbf{F})$ concentrations in the two layers $0.5-5 \mathrm{~m}(\mathbf{A}, \mathbf{C}, \mathbf{E})$ and $10-15 \mathrm{~m}(\mathbf{B}, \mathbf{D}, \mathbf{F})$.

The precipitation regime was characterised by a rainy period in late summer-autumn (September to November) and two drier periods in March-April and July-August (Figs 2C, 3C).

The annual cycle of the Isonzo River discharge displayed minima in summer and two maxima, the biggest one in autumn and a lower one in winter (Figs 2D, 3D). River flows in 2014 were particularly high (annual median, $95.97 \mathrm{~m}^{3} \mathrm{~s}^{-1}$ ), whereas scarce loads were recorded in 2011, 2012 and 2015 (annual medians, 8.51, 13.59 and $31.59 \mathrm{~m}^{3} \mathrm{~s}^{-1}$, respectively) (Fig. 3D).

Dissolved inorganic nitrogen (DIN) concentration ranged from undetectable values to $71.27 \mu \mathrm{mol} \mathrm{L}^{-1}$, measured in January 2014 at the surface (Fig. 4A, B). Concentrations were significantly higher $(H=64.86, p<0.001)$ in autumn-winter than in spring-summer (mean $\pm \mathrm{SD}, 3.79 \pm 5.34$ and $2.41 \pm 3.82 \mu \mathrm{mol} \mathrm{L}^{-1}$, respectively). Deviations from this cycle, with particularly high concentrations in the spring-summer period, occurred mainly in the surface layer. In 2010, 2013 and 2014, higher nitrogen concentrations (annual means \pm SD, $4.87 \pm 2.32,3.26 \pm 2.54$ and $5.05 \pm 5.26 \mu \mathrm{mol}$ $\mathrm{L}^{-1}$ ) than those recorded in other years (about $2.0 \mu \mathrm{mol} \mathrm{L}^{-1}$ ) were observed. The statistically significant differences were 2010 vs 2011, 2012, 2015, 2016 and 2017, 2014 vs $2017(H=44.58, p<0.001)$. 
Phosphate concentrations ranged from undetectable values to $0.28 \mu \mathrm{mol} \mathrm{L}^{-1}$ in June 2015 at the surface, and higher values were observed from late summer throughout autumn and winter, mainly in bottom waters (Fig. 4C, D).

Silicate concentrations ranged from $0.07 \mu \mathrm{mol} \mathrm{L}^{-1}$ in November 2010, at $5 \mathrm{~m}$ depth, to $40.73 \mu \mathrm{mol} \mathrm{L}^{-1}$ in January 2014 at the surface, with a mean value $( \pm$ SD) of $3.88 \pm 3.67 \mu \mathrm{mol} \mathrm{L}{ }^{-1}$. Silicate generally showed an increase in summer in the deeper waters (Fig. 4F). Occasionally, higher concentrations were observed at the surface (Fig. 4E).

The correlations among oceanographic variables and freshwater inputs, considering the seasons separately, are reported in Table 1. In the surface waters, in winter, salinity was negatively correlated with the Isonzo River discharge $(p<0.05)$, as well as DIN $(p<0.001)$ and $\mathrm{P}-\mathrm{PO}_{4}$ concentrations $(p<0.01)$. Temperature $(p<0.05)$, DIN $(p<0.05)$ and $\mathrm{Si}-\mathrm{Si}(\mathrm{OH})_{4}(p<0.01)$ concentrations were positively correlated with the riverine discharge. In spring, salinity was negatively correlated with temperature $(p$ $<0.001)$, Isonzo River discharge $(p<0.01)$, DIN and $\mathrm{Si}-\mathrm{Si}(\mathrm{OH})_{4}$ concentrations $(p<$ $0.001)$. DIN $(p<0.05)$ and $\mathrm{Si}-\mathrm{Si}(\mathrm{OH})_{4}(p<0.01)$ concentrations were positively correlated with the riverine discharge. In summer, salinity was inversely correlated with seawater temperature $(p<0.05)$. The riverine discharge was significantly correlated with precipitations $(p<0.05)$. Seawater temperature $(p<0.05)$ and $\mathrm{Si}-\mathrm{Si}(\mathrm{OH})_{4}$ concentrations $(p<0.05)$ correlated, respectively, inversely and directly with precipitations. Finally, in autumn, salinity was negatively correlated with precipitations $(p<$ $0.001)$, riverine discharge $(p<0.01)$, DIN $(p<0.001)$ and $\mathrm{P}_{-} \mathrm{PO}_{4}(p<0.05)$. Riverine discharge was positively correlated with precipitations $(p<0.01)$.

\section{Phytoplankton seasonal cycle}

Phytoplankton displayed a seasonal cycle characterised by minima in late autumnwinter (from December to February, with the monthly median always lower than 8.0 $\times 10^{5}$ cells $\mathrm{L}^{-1}$ at all depths) (Fig. 5).

In March, abundances started to increase, reaching the main peak in spring (May), with a median value of about $4 \times 10^{6}$ cells $\mathrm{L}^{-1}$ in the $0.5-5 \mathrm{~m}$ layer and about $2.3 \times$ $10^{6}$ cells $\mathrm{L}^{-1}$ at $10-15 \mathrm{~m}$, although these differences among depths were not statistically significant. From June, phytoplankton abundance gradually decreased and was low throughout the summer. Slightly higher abundances were observed at $10 \mathrm{~m}$ during this period. A further slight increase was observed in October (Fig. 5).

Considering the whole dataset, the phytoplankton community was dominated by flagellates (66\%) and diatoms (29\%), followed by coccolithophores and dinoflagellates (3 and 2\%, respectively), with all groups showing a marked seasonal cycle (Fig. 6).

On average, flagellates showed the highest abundances in spring-summer $(H=$ 127.46, $p<0.001$ ), from April to July, and minima in winter (Fig. 6A-B). The maximum abundance value $\left(5.6 \times 10^{6}\right.$ cells $\left.\mathrm{L}^{-1}\right)$ was recorded in July 2010 , at $5 \mathrm{~m}$ depth. Abundances were slightly higher in surface waters than in deeper ones, particularly in June 
Table I. Spearman rank correlations among oceanographic variables and freshwater inputs at surface in different seasons (WIN: winter; SPR: spring; SUM: summer; AUT: autumn). Significant values $(<5 \%)$ are marked in bold. ${ }^{*} p<0.05 ;{ }^{* *} p<0.01 ;{ }^{* * *} p<0.001$.

\begin{tabular}{|c|c|c|c|c|c|c|c|}
\hline WIN & Temperature & Salinity & Precipitation & Isonzo discharge & DIN & $\mathrm{P}_{-} \mathrm{PO}_{4}$ & $\mathrm{Si}-\mathrm{Si}(\mathrm{OH})_{4}$ \\
\hline Temperature & 1 & & & & & & \\
\hline Salinity & -0.241 & 1 & & & & & \\
\hline Precipitation & -0.036 & -0.289 & 1 & & & & \\
\hline Isonzo discharge & $0.497^{*}$ & $-0.439^{*}$ & 0.336 & 1 & & & \\
\hline DIN & $0.456^{*}$ & $-0.690^{* * *}$ & 0.199 & $0.528^{*}$ & 1 & & \\
\hline $\mathrm{P}_{-} \mathrm{PO}_{4}$ & 0.062 & $-0.529^{* *}$ & -0.017 & 0.220 & $0.549^{* *}$ & 1 & \\
\hline $\mathrm{Si}-\mathrm{Si}(\mathrm{OH})_{4}$ & 0.378 & -0.332 & 0.204 & $0.547^{* *}$ & $0.619^{* *}$ & $0.510^{*}$ & 1 \\
\hline SPR & Temperature & Salinity & Precipitation & Isonzo discharge & DIN & $\mathrm{P}_{-} \mathrm{PO}_{4}$ & $\mathrm{Si}-\mathrm{Si}(\mathrm{OH})_{4}$ \\
\hline Temperature & 1 & & & & & & \\
\hline Salinity & $-0.648^{* * *}$ & 1 & & & & & \\
\hline Precipitation & -0.299 & 0.265 & 1 & & & & \\
\hline Isonzo discharge & 0.253 & $-0.533^{* *}$ & 0.191 & 1 & & & \\
\hline DIN & 0.339 & $-0.805^{* * *}$ & -0.183 & $0.493^{*}$ & 1 & & \\
\hline $\mathrm{P}_{-} \mathrm{PO}_{4}$ & -0.334 & 0.073 & -0.071 & -0.006 & -0.030 & 1 & \\
\hline $\mathrm{Si}-\mathrm{Si}(\mathrm{OH})_{4}$ & $0.471^{*}$ & $-0.734^{* * *}$ & -0.203 & $0.580^{* *}$ & $0.773^{* * *}$ & 0.112 & 1 \\
\hline SUM & Temperature & Salinity & Precipitation & Isonzo discharge & DIN & $\mathrm{P}-\mathrm{PO}_{4}$ & $\mathrm{Si}-\mathrm{Si}(\mathrm{OH})_{4}$ \\
\hline Temperature & 1 & & & & & & \\
\hline Salinity & $-0.464^{*}$ & 1 & & & & & \\
\hline Precipitation & $-0.456^{*}$ & 0.113 & 1 & & & & \\
\hline Isonzo discharge & -0.289 & -0.108 & $0.448^{*}$ & 1 & & & \\
\hline DIN & -0.403 & -0.176 & 0.392 & 0.176 & 1 & & \\
\hline $\mathrm{P}_{-} \mathrm{PO}_{4}$ & -0.358 & 0.221 & 0.182 & -0.026 & 0.259 & 1 & \\
\hline $\mathrm{Si}-\mathrm{Si}(\mathrm{OH})_{4}$ & $-0.421^{*}$ & 0.234 & $0.476^{*}$ & 0.187 & $0.497^{*}$ & $0.430^{*}$ & 1 \\
\hline AUT & Temperature & Salinity & Precipitation & Isonzo discharge & DIN & $\mathrm{P}-P O_{4}$ & $\mathrm{Si}-\mathrm{Si}(\mathrm{OH})_{4}$ \\
\hline Temperature & 1 & & & & & & \\
\hline Salinity & -0.240 & 1 & & & & & \\
\hline Precipitation & 0.275 & $-0.683^{* * *}$ & 1 & & & & \\
\hline Isonzo discharge & 0.344 & $-0.609^{* *}$ & $0.630^{* *}$ & 1 & & & \\
\hline DIN & -0.117 & $-0.660^{* * *}$ & $0.504^{*}$ & 0.329 & 1 & & \\
\hline $\mathrm{P}_{-} \mathrm{PO}_{4}$ & -0.051 & $-0.422^{*}$ & 0.331 & 0.233 & $0.605^{* *}$ & 1 & \\
\hline $\mathrm{Si}-\mathrm{Si}(\mathrm{OH})_{4}$ & -0.003 & -0.238 & 0.004 & -0.056 & $0.471^{*}$ & $0.773^{* * *}$ & 1 \\
\hline
\end{tabular}

(Fig. 6A-B), but the differences were not statistically significant. The flagellate group was mainly represented by small $(<10 \mu \mathrm{m})$ forms of uncertain taxonomic identification $(80 \%)$, cryptophytes $(11 \%)$, prasinophytes $(4 \%)$ and prymnesiophytes $(2 \%)$, whereas chryso-, eugleno-, dictyochophytes and heterotrophic taxa accounted for only $3 \%$.

Diatoms showed minima from December to February (monthly median of about $10^{4}$ cells $\left.\mathrm{L}^{-1}\right)$, then increased in late winter and peaked in spring $(H=40.39, p<0.001)$, in May (monthly median $1.6 \times 10^{6}$ cells $\mathrm{L}^{-1}$ ) (Fig. $6 \mathrm{C}-\mathrm{D}$ ), with a maximum of $5.2 \times$ $10^{6}$ cells $\mathrm{L}^{-1}$ in May 2013 at the surface. In June, a remarkable decrease down to 2.1 $\times 10^{5}$ cells $\mathrm{L}^{-1}$ was observed and from July to September they attained very low abun- 


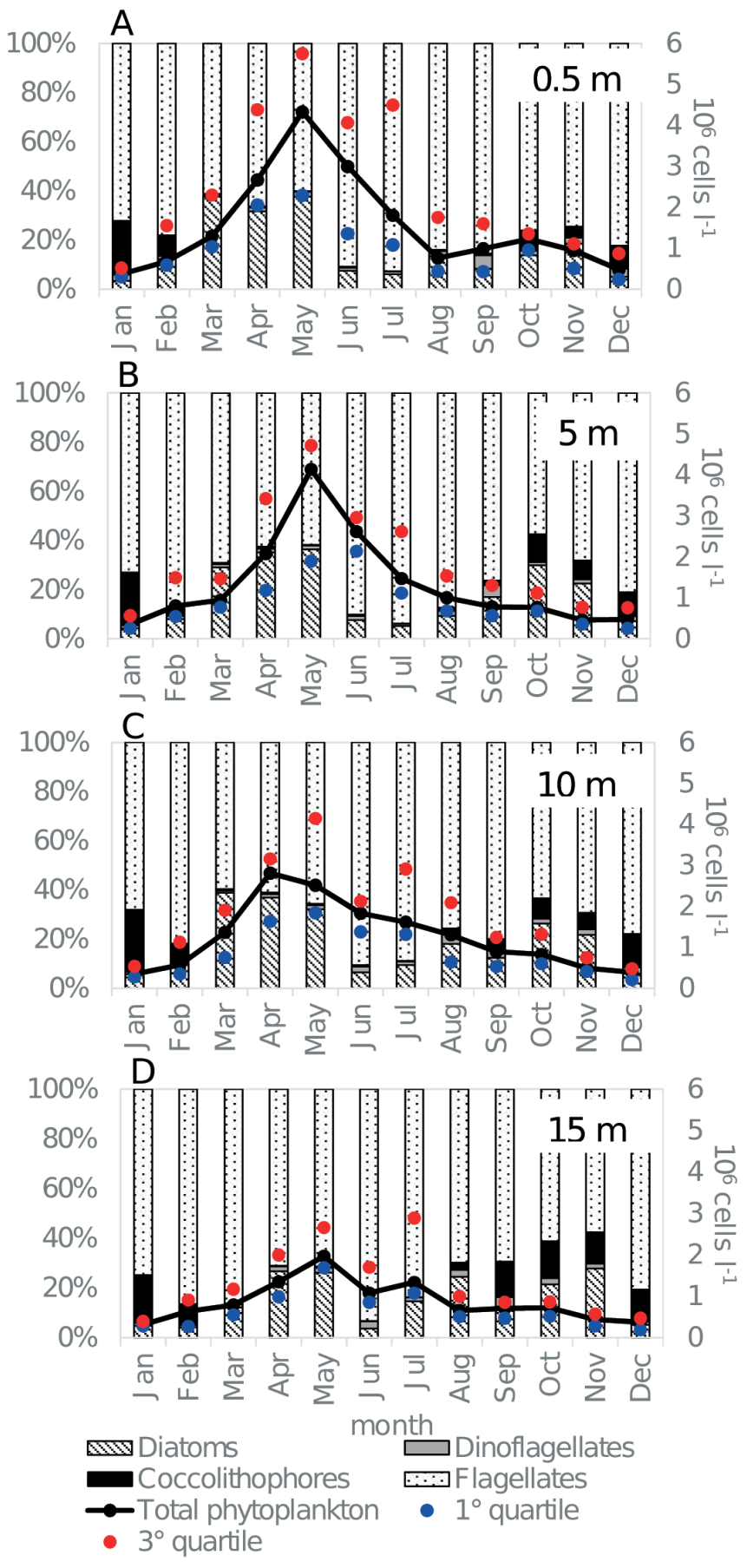

Figure 5. Monthly medians (black lines) and first and third quartiles (blue and red circles, respectively) of phytoplankton abundance and the relative contribution of the main phytoplankton groups (flagellates, diatoms, dinoflagellates, and coccolithophores) (bars) from 2010 to 2017 at the four sampled depths (0.5, 5, 10 and $15 \mathrm{~m}$ ) at the C1-LTER station. 

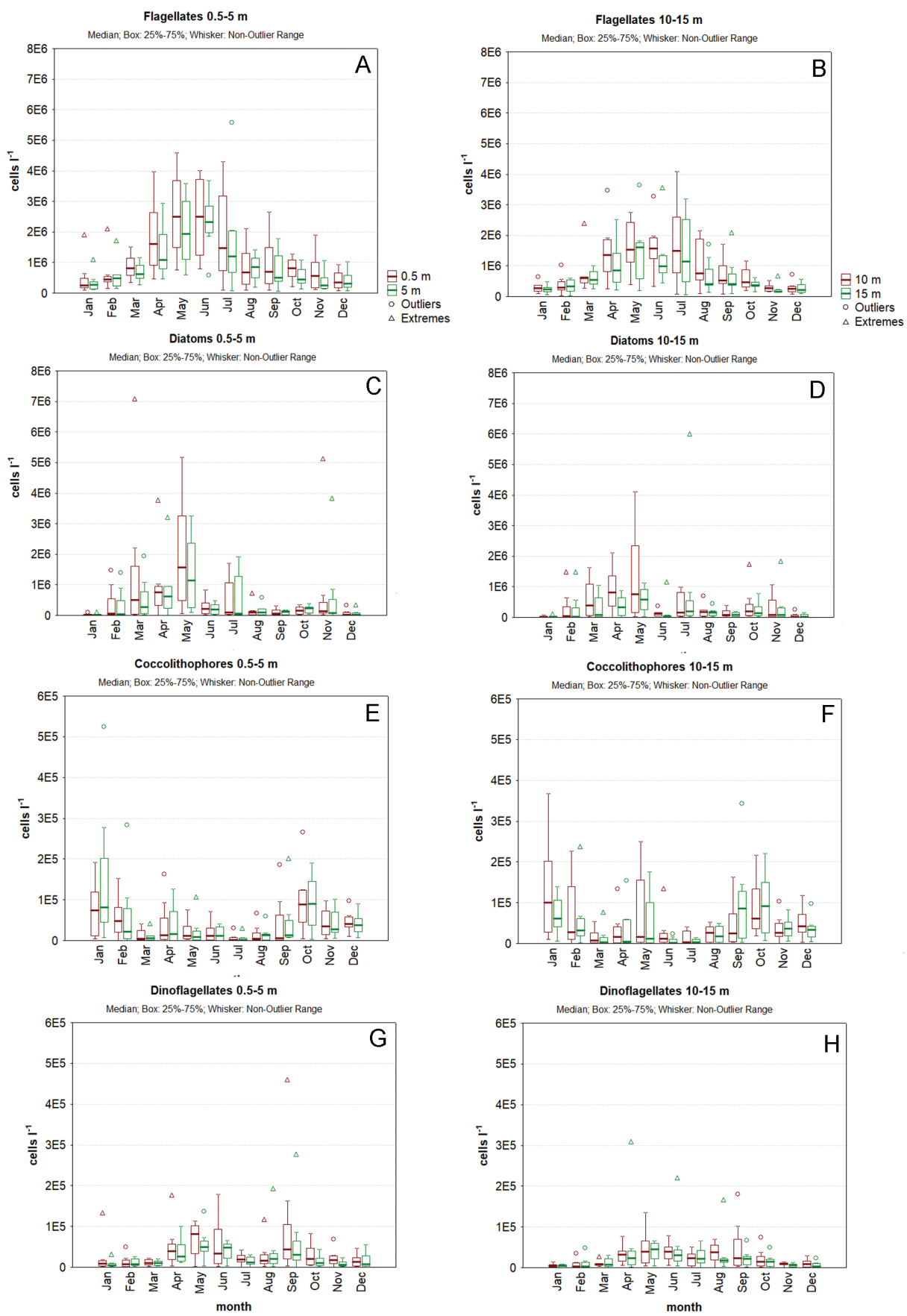

Figure 6. Seasonal cycle of flagellates (A-B), diatoms (C-D), coccolithophores (E-F) and dinoflagellates $(\mathbf{G}-\mathbf{H})$ at 0.5 and $5 \mathrm{~m}$ depth $(\mathbf{A}, \mathbf{C}, \mathbf{E}, \mathbf{G})$ and at 10 and $15 \mathrm{~m}$ depth $(\mathbf{B}, \mathbf{D}, \mathbf{F}, \mathbf{H})$. In the box plot, the bold line represents the median, the box the $25^{\text {th }}$ and $75^{\text {th }}$ percentiles of the distribution, the whisker the non-outlier range, the circle the outliers and the triangle the extremes. Note: $y$-scales are different for diatoms/flagellates and dinoflagellates/coccolithophores. 
dances (monthly median $<1.0 \times 10^{5}$ cells $\mathrm{L}^{-1}$ ), with occasional increases in July. A further, very low, increase was observed in October-November (monthly median 1.5 and $1.4 \times 10^{5}$ cells $\mathrm{L}^{-1}$, respectively). In winter, the most present taxa were Skeletonema spp., Pseudo-nitzschia spp. and Chaetoceros spp. The spring bloom was generally dominated by different small $(<20 \mu \mathrm{m})$ species of the genera Chaetoceros, Cyclotella and Bacteriastrum, replaced by larger species (e.g. Cerataulina pelagica (Cleve) Hendey, Pseudonitzschia spp. delicatissima complex, Leptocylindrus sp.) in summer and autumn.

Coccolithophores were most abundant in autumn-winter $(H=53.42, p<0.001)$ (Fig. 6E-F) with additional episodes of high abundance in May at 10 and $15 \mathrm{~m}$ (Fig. 6F). Emiliania huxleyi (Lohmann) W.W.Hay \& H.P.Mohler was the most abundant coccolithophore species (on average, $63 \%$ of the total coccolithophores), followed by undetermined forms (20\%), Ophiaster sp. (4\%), Acanthoica quattrospina Lohmann (4\%), Calciosolenia brasiliensis (Lohmann) J.R.Young (3\%), Rhabdolithes (formerly Rhabdosphaera) claviger (G.Murray \& Blackman) Voeltzkow (2\%) and Syracosphaera pulchra Lohmann (2\%).

Dinoflagellates showed higher abundances in spring and late summer $(H=94.18$, $p<0.001$ ) (Fig. 6G-H), with undetermined naked and thecate forms being the most abundant taxa (on average, 44.1 and $35.2 \%$ of the total dinoflagellates, respectively).

Diatoms were negatively correlated with DIN and silicates $(p<0.001)$, while dinoflagellates positively with temperature $(p<0.001)$ and negatively with DIN $(p<0.05)$ (Table 2). Coccolithophores showed a positive correlation with phosphates $(p<0.001)$ and silicates $(p<0.01)$, while flagellates were positively correlated with temperature $(p$ $<0.01)$ and negatively with salinity $(p<0.01)$, DIN $(p<0.001)$, phosphates $(p<0.01)$ and silicates $(p<0.05)$ (Table 2).

Phytoplankton assemblages were significantly diverse among seasons (Pseudo- $F=$ $9.59, p<0.01)$ and the IndVal calculation gave an indication of which species characterised different seasons (Table 3). Considering the species with an IndVal higher than 0.4, the winter season was characterised by only three taxa, the diatoms Skeletonema spp., the dictyochophyte Octactis octonaria (Ehrenberg) Hovasse and the heterotrophic taxon of choanoflagellates. In spring, a higher number of species was typical for the season: the small diatoms Cyclotella spp., Chaetoceros throndsenii (Marino, Montresor, \& Zingone) Marino, Montresor \& Zingone and Chaetoceros spp., a mixed assemblage of dinoflagellates (Torodinium robustum Kofoid \& Swezy, Prorocentrum cordatum (Ostenfeld) J.D.Dodge, Lessardia elongata Saldarriaga \& F.J.R.Taylor and undetermined naked forms), flagellates (undetermined cryptophytes, Leucocryptos marina (Braarud) Butcher, Commation sp., Ollicola vangoorii (W.Conrad) Vørs and Meringosphaera mediterranea Lohmann) and undetermined coccolithophores. The summer seasons were characterised by a mix of large diatoms (Proboscia alata (Brightwell) Sundström, Guinardia flaccida (Castracane) H.Peragallo, Rhizosolenia spp., Thalassionema spp., Cerataulina pelagica (Cleve) Hendey), dinoflagellates (Ceratoperidinium falcatum (Kofoid \& Swezy) Reñé \& Salas, Dinophysis fortii Pavillard, undetermined thecate dinoflagellates), the coccolithophore Rhabdolithes claviger (G.Murray \& Blackman) Voeltzkow and the prasinophyte Pseudoscourfieldia marina (J.Throndsen) Manton. Finally, in 
Phytoplankton temporal dynamics in the coastal waters of the north-eastern Adriatic Sea ... 357

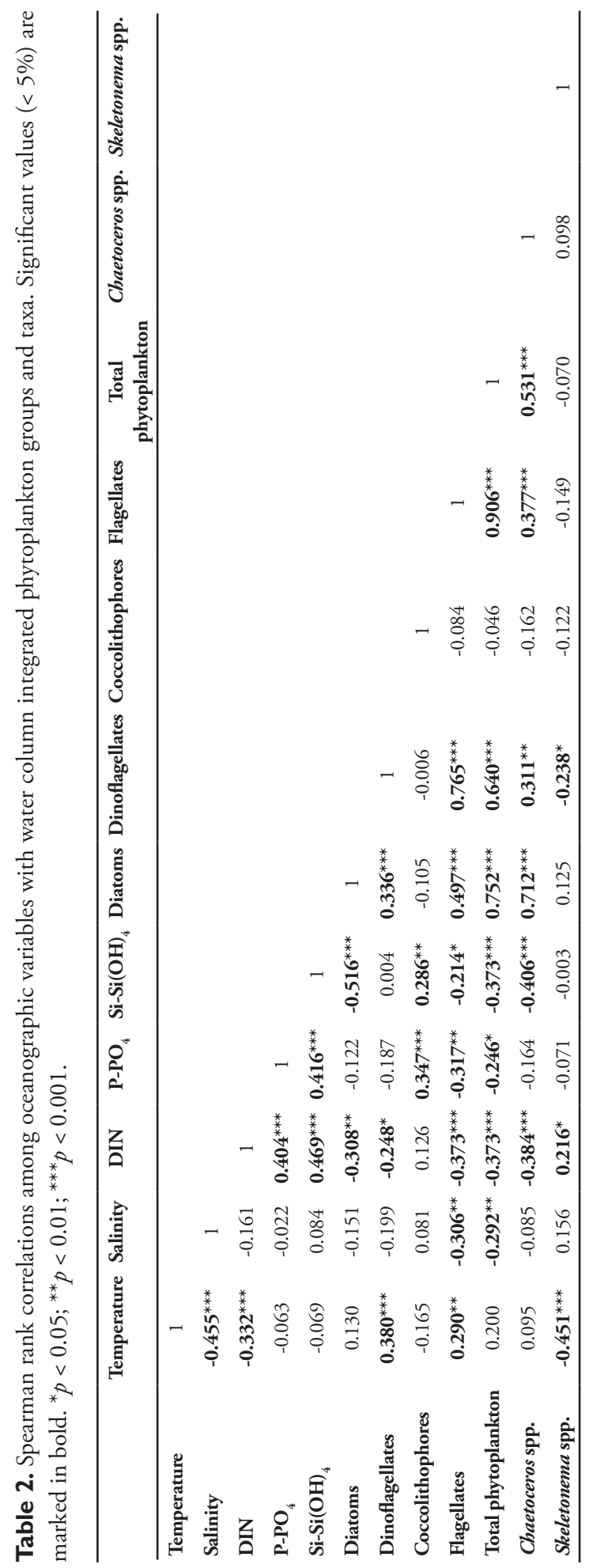


Table 3. List of phytoplankton taxa characterised by the highest and significant IndVal for each season (win: winter; spr: spring; sum: summer; aut: autumn).

\begin{tabular}{|c|c|c|c|}
\hline & Group & Indval & $p$-value \\
\hline Skeletonema spp. & win & 0.592 & 0.004 \\
\hline Und. choanoflagellates & win & 0.491 & 0.014 \\
\hline Octactis octonaria & win & 0.409 & 0.001 \\
\hline Protoperidinium bipes & win & 0.292 & 0.04 \\
\hline Cyclotella spp. & spr & 0.800 & 0.001 \\
\hline Prorocentrum micans & spr & 0.734 & 0.001 \\
\hline Chaetoceros throndsenii & spr & 0.724 & 0.001 \\
\hline Chaetoceros spp. & spr & 0.608 & 0.004 \\
\hline Torodinium sp. & spr & 0.590 & 0.001 \\
\hline Und. Cryptophyceae & spr & 0.576 & 0.001 \\
\hline Prorocentrum cordatum & spr & 0.517 & 0.006 \\
\hline Leucocryptos marina & spr & 0.516 & 0.002 \\
\hline Commation sp. & spr & 0.514 & 0.001 \\
\hline Ollicola vangoorii & spr & 0.507 & 0.001 \\
\hline Lessardia elongata & spr & 0.500 & 0.001 \\
\hline Meringosphaera mediterranea & spr & 0.484 & 0.001 \\
\hline Und. coccolithophores & spr & 0.427 & 0.001 \\
\hline Und. naked dinoflagellates & spr & 0.423 & 0.005 \\
\hline Diplopsalis group & spr & 0.414 & 0.001 \\
\hline Protoperidinium steinii & spr & 0.391 & 0.001 \\
\hline Alexandrium spp. & spr & 0.322 & 0.037 \\
\hline Und. Prymnesiophyceae & spr & 0.279 & 0.047 \\
\hline Dinobryon faculiferum & spr & 0.227 & 0.034 \\
\hline Proboscia alata & sum & 0.888 & 0.001 \\
\hline Hermesinum adriaticum & sum & 0.847 & 0.001 \\
\hline Ceratoperidinium falcatum & sum & 0.824 & 0.001 \\
\hline Guinardia flaccida & sum & 0.710 & 0.001 \\
\hline Und. pennate diatoms & sum & 0.668 & 0.001 \\
\hline Rhizosolenia spp. & sum & 0.611 & 0.001 \\
\hline Asteromphalus spp. & sum & 0.586 & 0.001 \\
\hline Pseudoscourfieldia marina & sum & 0.571 & 0.002 \\
\hline Rhabdolithes claviger & sum & 0.508 & 0.001 \\
\hline Thalassionema spp. & sum & 0.498 & 0.013 \\
\hline Und. thecate dinoflagellates & sum & 0.453 & 0.016 \\
\hline Dinophysis fortii & sum & 0.451 & 0.001 \\
\hline Cerataulina pelagica & sum & 0.434 & 0.050 \\
\hline Tripos furca & sum & 0.395 & 0.005 \\
\hline Gyrodinium spp. & sum & 0.387 & 0.026 \\
\hline Hemiaulus hauckii & sum & 0.364 & 0.004 \\
\hline Gonyaulax polygramma & sum & 0.340 & 0.005 \\
\hline Chaetoceros lorenzianus & sum & 0.320 & 0.008 \\
\hline Prorocentrum dactylus & sum & 0.312 & 0.010 \\
\hline Dinophysis caudata & sum & 0.300 & 0.009 \\
\hline Leptocylindrus mediterraneus & sum & 0.280 & 0.021 \\
\hline Bacteriastrum jadranum & sum & 0.269 & 0.016 \\
\hline Phalacroma rotundatum & sum & 0.268 & 0.025 \\
\hline Syracosphaera pulchra & aut & 0.776 & 0.001 \\
\hline Calciosolenia murrayi & aut & 0.700 & 0.001 \\
\hline Diploneis spp. & aut & 0.638 & 0.001 \\
\hline Dactyliosolen blavyanus & aut & 0.594 & 0.001 \\
\hline Lioloma pacificum & aut & 0.546 & 0.001 \\
\hline Ophiaster spp. & aut & 0.505 & 0.001 \\
\hline Guinardia striata & aut & 0.447 & 0.002 \\
\hline Asterionellopsis glacialis & aut & 0.435 & 0.001 \\
\hline Dictyocha fibula & aut & 0.369 & 0.011 \\
\hline Chaetoceros socialis & aut & 0.363 & 0.001 \\
\hline Und. Euglenophyceae & aut & 0.352 & 0.027 \\
\hline Paralia sulcata & aut & 0.260 & 0.029 \\
\hline
\end{tabular}




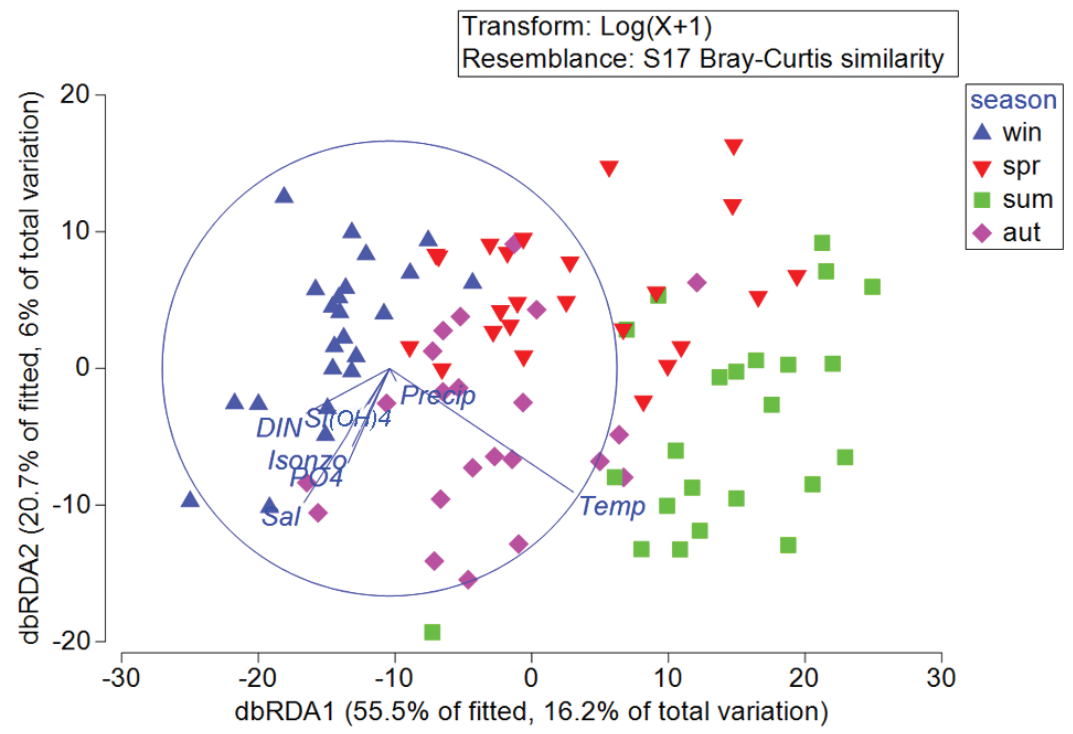

Figure 7. Distance-based redundancy analysis (dbRDA) plot of phytoplankton assemblages. Vectors of abiotic variables (temp: temperature; sal: salinity; precip: total precipitations in the three days preceding the sampling; Isonzo: Isonzo River discharge in the seven days preceding the sampling; DIN: dissolved inorganic nitrogen concentration; PO4: phosphate concentration; $\mathrm{Si}(\mathrm{OH}) 4$ : silicate concentration) affect the construction of the constrained ordination picture; the longer the vector, the bigger the effect of the variable.

autumn, very few species were typical, some coccolithophores (Syracosphaera pulchra Lohmann, Calciosolenia murrayi Gran, Ophiaster sp.) and some large diatoms (Dactyliosolen blavyanus (H.Peragallo) Hasle, Lioloma pacificum (Cupp) Hasle, Guinardia striata (Stolterfoth) Hasle, Asterionellopsis glacialis (Castracane) Round).

The dbRDA analysis also revealed temporal differences of phytoplankton assemblages (Fig. 7), with summer and winter samples well-separated, whereas autumn and spring samples were slightly overlapping. Temperature and salinity proved to be the best predictor variables, explaining the greatest variations in the data cloud: dbRDA1 was strongly correlated with temperature $(r=0.81)$, while dbRDA2 was related to salinity $(\mathrm{r}=-0.59)$. Phosphate showed a moderate correlation with dbRDA2. Temperature was associated with summer assemblages, salinity and Isonzo River discharge with autumn samples, and nutrients with winter samples.

\section{Phytoplankton interannual variability}

The temporal distribution from January 2010 to December 2017 of water column integrated abundance values of the main phytoplankton groups showed interannual variability for maximum values and occurrence of these maxima (Fig. 8).

The two main taxonomic groups were flagellates and diatoms during the whole analysed period, with a predominance of flagellates (annual medians $>6 \times 10^{5}$ cells 
$\mathrm{L}^{-1}$ for flagellates, $<2 \times 10^{5}$ cells $\mathrm{L}^{-1}$ for diatoms). Two exceptions were observed in 2011 and 2012, when flagellates showed particularly low abundances (annual median 1.7 and $4.5 \times 10^{5}$ cells $\mathrm{L}^{-1}$, respectively) (Fig. 8B). Particularly high flagellate abundances were recorded in July 2010 (up to $5.6 \times 10^{6}$ cells $\mathrm{L}^{-1}$ at $5 \mathrm{~m}$ ), even though the highest annual median $\left(1.2 \times 10^{6}\right.$ cells L $\left.^{-1}\right)$ was observed in 2016. Diatoms showed low interannual variability in their annual median values (between 4.5 $\times 10^{4}$ and $1.1 \times 10^{5}$ cells $\mathrm{L}^{-1}$ from 2011 to 2016 and about $2.0 \times 10^{5}$ cells $\mathrm{L}^{-1}$ in 2010 and 2017). However, annual peaks varied in abundance and occurrence (Fig. 8C). During the first years (2010-2012) of the analysed period, diatom increases were observed in late winter-early spring (March-April): in 2010, due to C. simplex Ostenfeld (mean March-April along the water column $3.5 \times 10^{5}$ cells L $^{-1}$ ), Pseudo-nitzschia spp. delicatissima complex $\left(1.1 \times 10^{5}\right.$ cells $\left.\mathrm{L}^{-1}\right)$ and Skeletonema spp $\left(1.0 \times 10^{5}\right.$ cells $\left.\mathrm{L}^{-1}\right)$; in 2011 , due to Chaetoceros spp. $\left(1.2 \times 10^{5}\right.$ cells L $\left.^{-1}\right)$, Pseudo-nitzschia spp. seriata complex $\left(7.3 \times 10^{5}\right.$ cells $\left.\mathrm{L}^{-1}\right)$ and Skeletonema spp. $\left(1.7 \times 10^{6}\right.$ cells $\left.\mathrm{L}^{-1}\right)$; in 2012 , due

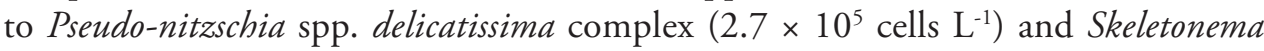
spp. $\left(3.5 \times 10^{4}\right.$ cells L $\left.{ }^{-1}\right)$. From 2013 onwards, Skeletonema spp. abundances decreased significantly (never higher than $9.2 \times 10^{3}$ cells L $^{-1}$ ) in winter and blooms were recorded in spring (May) (with highly variable maximum abundance values), due to different species belonging to the Chaetoceros, Bacteriatrum and Cyclotella genera. In 2010, additional high diatom increases were detected in July $(0.5-15 \mathrm{~m}$-integrated abundance $2.0 \times 10^{6}$ cells $\mathrm{L}^{-1}$, maximum $6.0 \times 10^{6}$ cells $\mathrm{L}^{-1}$ at $15 \mathrm{~m}$ ) and November (0.5-15 m-integrated abundance $2.3 \times 10^{6}$ cells $\mathrm{L}^{-1}$, maximum $5.1 \times 10^{6}$ cells $\mathrm{L}^{-1}$ at the surface). The main species present in July were Pseudo-nitzschia spp. delicatissima complex $\left(5.2 \times 10^{6}\right.$ cells L $\mathrm{L}^{-1}$ at $\left.15 \mathrm{~m}\right)$, Chaetoceros cf. simplex $\left(3.3 \times 10^{5}\right.$ cells L $^{-1}$ at 15 $\mathrm{m})$ and C. socialis H.S. Lauder $\left(1.0 \times 10^{5}\right.$ cells $\mathrm{L}^{-1}$ at $\left.15 \mathrm{~m}\right)$, whereas in November it

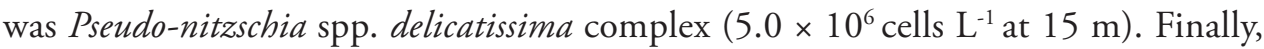
the lowest diatom abundances were recorded in 2012.

Coccolithophores displayed the typical seasonal cycle, with the highest abundances in autumn-winter, in all investigated years (Fig. 8D); however, additional increases were observed in 2010, 2011, 2014 and 2017. In August 2010, a very unusual peak $\left(1.5 \times 10^{6}\right.$ cells $\left.\mathrm{L}^{-1}\right)$ due to Emiliania huxleyi was recorded at $15 \mathrm{~m}$ depth, whereas abundance in the upper layer $(0.5-10 \mathrm{~m})$ was very low. In May 2011, high E. huxleyi abundance $\left(2.5 \times 10^{5}\right.$ cells $\left.\mathrm{L}^{-1}\right)$ was recorded only at $10 \mathrm{~m}$ depth, whereas in 2014 and 2017 the increase in April-May was noted at all depths and was due to more species, $E$. huxleyi, Acanthoica quattrospina, Ophiaster sp. and undetermined coccolithophores. In 2012, 2013 and 2016, coccolithophore abundances were lower (annual medians lower than $2.0 \times 10^{4}$ cells L $^{-1}$ ) than those observed in 2010, 2011, 2014 and 2015 (annual medians between 2.9 and $3.7 \times 10^{4}$ cells L $^{-1}$ ), whereas in 2017 higher values (annual median $5.5 \times 10^{4}$ cells $\mathrm{L}^{-1}$ ) were recorded.

Dinoflagellates were always present in spring-summer (Fig. 8E) with the lowest annual median in $2011\left(2.9 \times 10^{3}\right.$ cells L $\left.^{-1}\right)$ and the highest in $2013\left(3.3 \times 10^{4}\right.$ cells $\left.\mathrm{L}^{-1}\right)$. Sometimes, higher abundances were recorded at specific depths, generally due to undetermined naked and thecate forms. For instance, in September 2015, the highest density was observed at $0.5-5 \mathrm{~m}\left(4.6\right.$ and $2.8 \times 10^{5}$ cells L $\left.^{-1}\right)$. 

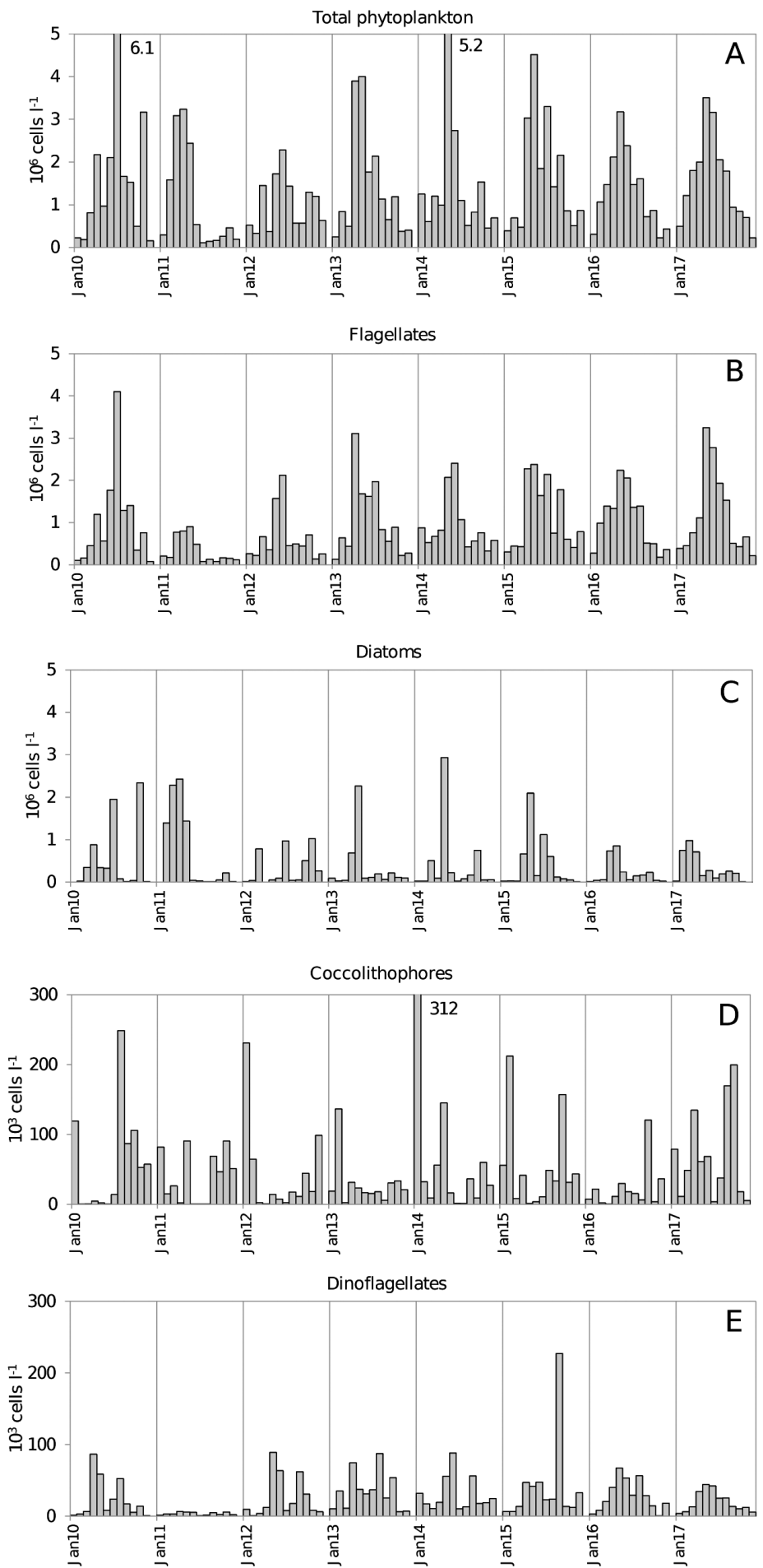

Figure 8. Temporal variations from January 2010 to December 2017 of depth integrated abundances of total phytoplankton $(\mathbf{A})$, flagellates $(\mathbf{B})$, diatoms $(\mathbf{C})$, coccolithophores $(\mathbf{D})$ and dinoflagellates $(\mathbf{E})$. 


\section{Discussion}

\section{Seasonal cycle}

This study presents the temporal dynamics, over eight years, of the phytoplankton community at a coastal station located in the north-eastern Adriatic, a highly variable environment. A marked seasonality, with warm summers and cool winters, was observed, which is typical of the area (Cossarini et al. 2012). Phytoplankton also showed a marked seasonal cycle with a maximum in spring (May), a gradual decrease during the summer, a further small increase in October and the lowest values in winter.

Phytoplankton attained minimum values in winter, in contrast to a previous study (Cabrini et al. 2012), covering 25 years (1986-2010), which described a phytoplankton annual cycle characterised by a late winter-early spring peak dominated by flagellates and the diatoms Pseudo-nitzschia spp., Skeletonema marinoi Sarno \& Zingone, Thalassiosira spp., and Chaetoceros spp.. Instead, in the period 2010-2017, a spring bloom characterised the median seasonal cycle as previously observed in different area of the Adriatic Sea such as the north-western (Bernardi Aubry et al. 2012), northeastern (Mozetić et al. 2012) and middle basin (Totti et al. 2000). Diatoms and flagellates (forms generally $<10 \mu \mathrm{m}$ in size) generally co-occurred during this period, as reported by Ribera d'Alcalà et al. (2004) in the Tyrrhenian Sea, but in contrast to the general findings in other Mediterranean areas where phytoplankton maxima are often dominated by diatoms (e.g. Nunes et al. 2018). In the north-eastern Adriatic, a dominance of nanoflagellates was often observed in spring (Marić et al. 2012; Mozetić et al. 2012; Godrijan et al. 2013; Talaber et al. 2014). Mozetić et al. (2012) explained that this could be due to the lack of control by their grazers, the microzooplankton, that indeed showed a strong reduction of their spring peak in the period 1998-2010 compared to the period 1986-1990 (Monti et al. 2012). Diatoms peaking in spring were also nano-sized, generally small (often $<15 \mu \mathrm{m}$ ) species belonging to genera Cyclotella, Bacteriastrum and Chaetoceros (solitary or colonial species). This contradicts the general view of the typical spring diatom assemblages often being dominated by large species, such as Pseudo-nitzschia and large Chaetoceros, (e.g. Ribera d'Alcalà et al. 2004; Daniels et al. 2015). However, Daniels et al. (2015), who investigated the dynamics of the phytoplankton community structure at two contrasting sites in the Icelandic and Norwegian basins, found that the typical large diatoms dominated the spring bloom in the Icelandic basin, while very small (even $<5 \mu \mathrm{m}$ ) diatoms dominated in the Norwegian basin. Similarly, Leblanc et al. (2018) described a massive spring bloom of the smallest known diatoms (Minidiscus) in the northwest Mediterranean Sea and, using a metabarcoding approach, showed the importance of this diatom at global scale. The dominance of nano-sized species in a spring bloom could have noteworthy implications for carbon export because larger phytoplankton cells more easily sink and, eaten by zooplankton, are exported to the bottom as fecal pellets, whereas smaller organisms are shifted towards the microbial loop, thereby reducing the efficiency of the carbon pump. On the contrary, Leblanc et al. (2018) evidenced high sinking rates for Minidis- 
cus, thus demonstrating its important role in the export of carbon to deep oceans. The spring bloom could be triggered by higher nutrient availability in the period MarchMay, especially in surface waters due to riverine discharges, as shown by the significant correlations with salinity and with $\mathrm{DIN}$ and $\mathrm{Si}-\mathrm{Si}(\mathrm{OH})_{4}$. After May, phytoplankton abundances progressively decreased and attained low values in the summer. This differs from other northern Adriatic areas where summer blooms were reported, often due to diatoms (Bernardi Aubry et al. 2004, 2012; Kraus and Supić 2011; Marić et al. 2012; Mozetić et al. 2012; Godrijan et al. 2013; Talaber et al. 2014). In the northern Adriatic, these blooms were related to the spreading of the Po River plume towards the Istrian coast, carrying low salinity water with high inorganic nitrogen concentration (Godrijan et al. 2013; Viličić et al. 2013) or to episodic events of precipitations in the southern part of the Gulf of Trieste (Mozetić et al. 2012). In the northern part of the Gulf of Trieste, low Isonzo River discharge and low precipitations characterised the summer months, with the exception of some episodic storms in August that actually can cause episodic diatom increases. Seawater temperature reached maximum values and the water column was stratified with low inorganic nitrogen concentration. A mix of large diatoms and dinoflagellates, along with the coccolithophore Rhabdolithes claviger and the flagellate Pseudoscourfieldia marina, were typical of the period. The increase in the number of dinoflagellates is a typical feature of the summer period throughout the northern Adriatic (Bernardi Aubry et al. 2004, 2006; Ninčević Gladan et al. 2010; Cabrini et al. 2012; Marić et al. 2012) as shown by the positive correlation with temperature, also found by Ninčević Gladan et al. (2010). Generally, non-redtide dinoflagellates are reported to be well-adapted to thermal stratification conditions with low nutrient availability (Latasa et al. 2010). The coccolithophore Rhabdolithes claviger was also identified as a distinctive summer coccolithophore in the Adriatic Sea (Bernardi Aubry et al. 2006; Godrijan et al. 2013; Cerino et al. 2017; Godrijan et al. 2018) as well as in other Mediterranean areas (Cros and Fortuño 2002; Dimiza et al. 2015; Karatsolis et al. 2017) and in thermal stratified waters worldwide (Okada and McIntyre 1977; Hagino et al. 2000). It is reported to be related to high temperature and low nitrate concentrations (Haidar and Thierstein 2001; Bernardi Aubry et al. 2006; Godrijan et al. 2013).

In late summer, the increase of silicates in deeper waters, under the pycnocline, as also observed in previous works (Cossarini et al. 2012), could be related to the degradation of diatoms.

In autumn, the high nutrient availability due to the riverine discharges and mixing of the water column and the still favourable light conditions triggered a second phytoplankton increase, although much smaller. Autumn blooms have been reported in the Gulf of Trieste (Cabrini et al. 2012; Mozetić et al. 2012) and in other areas of the north-eastern Adriatic Sea (Kraus and Supić 2011; Marić et al. 2012; Godrijan et al. 2013; Talaber et al. 2014). However, Mozetić et al. (2012) and Marić et al. (2012) observed a strong reduction in amplitude of this bloom from the period 1989-2002 to 2003-2009 and from 1972-1999 to 2000-2009, respectively. Coccolithophores (Syracosphaera pulchra, Calciosolenia murrayi, Ophiaster sp.) and some large diatoms 
(Dactyliosolen blavyanus, Lioloma pacificum, Guinardia striata, Asterionellopsis glacialis) were typical of this period. The presence of coccolithophores in autumn assemblages has already been reported in the eastern Adriatic Sea (Šupraha et al. 2011; Cabrini et al. 2012; Cerino et al. 2017; Godrijan et al. 2018; Skejić et al. 2018). In general, autumn coccolithophores are related to high nutrient concentrations (Godrijan et al. 2013), as indicated by the positive correlation between coccolithophores and phosphate concentration. Moreover, the positive correlation between coccolithophore abundance and silicates could be explained by the role of silicates in the calcification process of some coccolithophores (Durak et al. 2016).

\section{Interannual variability}

In recent decades, the Gulf of Trieste has experienced considerable changes in its oceanographic, biogeochemical and biological features (Giani et al. 2012). Some of these changes are still ongoing and can affect phytoplankton abundance and dynamics. Obviously, eight years are not sufficient to support the existence of trends; however, the analysis of multi-annual periods can help to distinguish between interannual variability and possible ongoing long-term changes in phytoplankton dynamics.

Changes in phytoplankton abundances have been extensively reported at both global (e.g. Rousseaux and Gregg 2015) and local scale. For instance, in the Adriatic Sea, in the past years, different studies, using datasets of varying time spans, have reported regime shifts of chlorophyll a concentrations (Ninčević Gladan et al. 2010; Mozetić et al. 2010) and phytoplankton abundances (Cabrini et al. 2012; Marić et al. 2012; Mozetić et al. 2012; Ljubimir et al. 2017). Cabrini et al. (2012), analysing a long-term dataset (1986-2010) of phytoplankton abundances in the same area in the Gulf of Trieste, described two shifts, one in 1995 with a decrease of phytoplankton abundances and another in 2009 with an increase, but concluded that the shortness of the second period (2009-2010) did not allow for stating the beginning of a new regime. Analysing the years immediately after (2010-2017), the upward trend observed by Cabrini et al. (2012) was confirmed.

The most striking change recorded during this study was the strong decrease of the phytoplankton annual maximum in late winter-early spring, typical of the study area (Cabrini et al. 2012; Cibic et al. 2018). Changes in phytoplankton maxima over the seasonal cycle have already been reported in the Adriatic Sea (Viličić et al. 2009; Mozetić et al. 2010; Marić et al. 2012). Nanoflagellates and diatoms dominated this maximum, and among diatoms, Skeletonema spp., Chaetoceros spp. and Pseudonitzschia spp. delicatissima complex were the most representative taxa. The bloom decrease was due mainly to a strong reduction of Skeletonema spp. abundance compared to previous years, during the 1986-2000 period in particular, when this genus was the main taxon of late winter-early spring blooms (Cabrini et al. 2012). The taxon we reported as Skeletonema spp. was never characterised via electron microscopy or molecular markers; therefore, we prefer to refer to Skeletonema spp.. However, it is most probably $S$. marinoi (former $S$. costatum), which is extensively reported as being 
responsible for the winter-early spring blooms in the northern Adriatic Sea (Sarno et al. 2005; Marić Pfannkuchen et al. 2018). The decrease of this species had already been observed in the area by Cabrini et al. (2012) who suggested the nutrient reduction as a possible cause. However, the temperature increase could have also played a role in this decline. Indeed, this species was reported as typical of cold waters (Bernardi Aubry et al. 2004) and laboratory experiments also confirmed the preference of this species for temperature below $10{ }^{\circ} \mathrm{C}$ (Kaeriyama et al. 2011). Accordingly, a negative correlation between Skeletonema spp. and temperature was observed and in the period 2010-2012, when high Skeletonema spp. abundances were recorded, mean annual seawater temperatures in winter were very low compared to the period 2013-2017. The increase of surface water temperature in the northern Adriatic Sea (Degobbis et al. 2000; Solidoro et al. 2009; Giani et al. 2012) and worldwide in coastal environments (Lima and Wethey 2016) is generally recognised. A warming trend, with an increase in surface water temperature, particularly intensified since 2008 , of about $1.1^{\circ} \mathrm{C}$ in the period 1979-2015, has been observed along the eastern Adriatic coast, although the authors pointed out the existence of multidecadal sea temperature variability (Grbec et al. 2018). A decrease in Skeletonema abundances has also been reported for Narragansett Bay in the period 1980-1997 with the decline being greatest during the winter-spring bloom (Borkman and Smayda 2009). The authors proposed an influence of the North Atlantic Oscillation (NAO); therefore, the years with low NAO tended to have colder winters and the winter-spring bloom dominated the Skeletonema annual cycle. A decline in Skeletonema dominance replaced by Chaetoceros was also observed in the eastern Seto Inland Sea (Nishikawa et al. 2010). However, longer observations are needed to definitively support the view that temperature is possibly responsible for the Skeletonema bloom decrease, and other factors should be considered. The diversity and dynamics of phytoplankton assemblages are complex processes driven by several interacting abiotic and biotic factors and, in addition to other physical-chemical drivers, biological interactions, such as grazing pressure and/or viral infections can have a role in shaping phytoplankton assemblages. The implications of a decreased bloom can be significant if one considers the importance of the synchronisation of the phenological cycles of primary producers and their consumers for matter and energy transfer through the food web (e.g., Edwards and Richardson 2004; Thackeray et al. 2016; Kodama et al. 2018). In the same way, changes in the composition of these blooms can also affect consumers because the food quality of various species can differ both in terms of stoichiometric composition and morphological characteristics, such as the presence of setae or cell projections (e.g., Finkel et al. 2010).

\section{Conclusions}

Long-term sampling offers a unique opportunity to analyse multiannual datasets and describe complete seasonal cycles, thus unveiling possible changes occurring in phytoplankton community structure in highly variable environments such as coastal ecosys- 
tems where the distinction between natural variability and temporal trends is more difficult due to local disturbances. In the north-eastern part of the Gulf of Trieste, phytoplankton displayed a marked seasonal cycle strongly influenced by temperature and salinity, as revealed by multivariate analysis. This cycle was characterised by a spring peak dominated by nanoflagellates and small diatoms, triggered by high nutrient availability due to riverine discharges, and a second small increase in autumn dominated by nanoflagellates, larger diatoms and coccolithophores, possibly favoured by higher nutrient availability deriving from the mixing of the water column. In summer, stormy events could cause episodic diatom increases. At interannual scale, a strong decrease of the late winter-early spring bloom was observed in recent years, with the spring bloom becoming the main peak during the year. If the role of temperature will be confirmed with further analyses, it may have significant implications in the view of climate changes as drivers of long-term changes in phytoplankton dynamics. However, because long-term data series are considered necessary to determine whether the changes are actual ongoing trends, or fall within the interannual variability of phytoplankton communities, continuous monitoring of these alterations is very important. Therefore, LTER sites offer ideal study fields for this purpose and provide data for defining the environmental status, as required by the Marine Strategy. Additionally, the LTER-Italy network allows for sharing methodologies, ecological data and knowledge which would provide the opportunity to establish collaborations at the national (with other LTER-Italy sites), regional (LTER- Europe) and international (LTER-International) levels.

\section{Acknowledgements}

The Gulf of Trieste site is part of the national and international Long Term Ecological Research networks (LTER-Italy, LTER-Europe, ILTER). The authors would like to thank Paola Del Negro for continuing to promote long-term research in the Gulf of Trieste, Bruno Cataletto, Cinzia Comici and Edvino Cociancich for sampling and performing CTD measurements and the Riserva Marina di Miramare and ARPA-FVG for providing the vessels. The authors are grateful to ISMAR-CNR Trieste for providing data on total precipitations and to "Regione Autonoma Friuli Venezia Giulia, Direzioni centrali dell'amministrazione regionale, Direzione centrale ambiente ed energia, Area tutela geologico-idrico-ambientale, Servizio disciplina servizio idrico integrato, gestione risorse idriche, tutela acque da inquinamento" for providing Isonzo River hydrometric data. The authors also thank the subject editor and reviewers for their constructive comments and suggestions that helped to improve the paper.

\section{References}

Bernardi Aubry F, Berton A, Bastianini M, Socal G, Acri F (2004) Phytoplankton succession in a coastal area of the NW Adriatic, over a 10-year sampling period (1990-1999). Continental Shelf Research, 24: 97-115. https://doi.org/10.1016/j.csr.2003.09.007 
Bernardi Aubry F, Acri F, Bastianini M, Bianchi F, Cassin D, Pugnetti A, Socal G (2006) Seasonal and interannual variations of phytoplankton in the Gulf of Venice (Northern Adriatic Sea). Chemistry and Ecology 22: S71-S91. https://doi.org/10.1080/02757540600687962

Bernardi Aubry F, Cossarini G, Acri F, Bastianini M, Bianchi F, Camatti E, De Lazzari A, Pugnetti A, Solidoro C, Socal G (2012) Plankton communities in the Northern Adriatic: patterns and changes over last 30 years. Estuarine, Coastal and Shelf Sciences 115: 125-137. https://doi.org/10.1016/j.ecss.2012.03.011

Borkman DG, Smayda T (2009) Multidecadal (1959-1997) Changes in Skeletonema abundance and seasonal bloom patterns in Narragansett Bay, Rhode Island, USA. Journal of Sea Research 61: 84-94. https://doi.org/10.1016/j.seares.2008.10.004

Cabrini M, Fornasaro D, Cossarini G, Lipizer M, Virgilio D (2012) Phytoplankton temporal changes in a coastal northern Adriatic site during the last 25 years. Estuarine, Coastal and Shelf Science 115: 113-124. https://doi.org/10.1016/j.ecss.2012.07.007

Cerino F, Malinverno E, Fornasaro D, Kralj M, Cabrini M (2017) Coccolithophore diversity and dynamics at a coastal site in the Gulf of Trieste (northern Adriatic Sea). Estuarine, Coastal and Shelf Science 196: 331-345. https://doi.org/10.1016/j.ecss.2017.07.013

Cibic T, Cerino F, Karuza A, Fornasaro D, Comici C, Cabrini M (2018) Structural and functional response of phytoplankton to reduced river inputs and anomalous physical-chemical conditions in the Gulf of Trieste (northern Adriatic Sea). Science of the Total Environment 636: 838-853. https://doi.org/10.1016/j.scitotenv.2018.04.205

Cossarini G, Solidoro C, Fonda Umani S (2012) Dynamics of biogeochemical properties in temperate coastal areas of freshwater influence: Lessons from the Northern Adriatic Sea (Gulf of Trieste). Estuarine, Coastal and Shelf Science 115: 63-74. https://doi. org/10.1016/j.ecss.2012.02.006

Cozzi S, Falconi C, Comici C, Čermelj B, Kovac N, Turk V, Giani M (2012) Recent evolution of river discharges in the Gulf of Trieste and their potential response to climate changes and anthropogenic pressure. Estuarine, Coastal and Shelf Science 115: 14-24. https://doi. org/10.1016/j.ecss.2012.03.005

Cros L, Fortuño J-M (2002) Atlas of northwestern Mediterranean coccolithophores. Scientia Marina 66: 7-182. https://doi.org/10.3989/scimar.2002.66s11

Daniels CJ, Poulton AJ, Esposito M,Paulsen ML, Bellerby R, St John M, Martin AP (2015) Phytoplankton dynamics in contrasting early stage North Atlantic spring blooms: composition, succession, and potential drivers. Biogeosciences 12: 2395-2409. https://doi. org/10.5194/bg-12-2395-2015

Degobbis D, Precali R, Ivancic I, Smodlaka N, Fuks D, Kveder S (2000) Long-term changes in the northern Adriatic ecosystem related to anthropogenic eutrophication. International Journal of Environment and Pollution 13: 495-533. https://doi.org/10.1504/ IJEP.2000.002332

Dimiza MD, Triantaphyllou MV, Malinverno E, Psarra E, Karatsolis B-T, Mara P, Lagaria A, Gogou A (2015) The composition and distribution of living coccolithophores in the Aegean Sea (NE Mediterranean). Micropaleontology 61: 521-540.

Dufrêne M, Legendre P (1997) Species assemblages and indicator species: the need for a flexible asymmetrical approach. Ecological Monographs 67: 345-366. https://doi. org/10.2307/2963459 
Durak GM, Taylor AR, Walker CE, Probert I, de Vargas C, Audic S, Schroder D, Brownlee C, Wheeler GL (2016) A role for diatom-like silicon transporters in calcifying coccolithophores. Nature Communications 7: 10543. https://doi.org/10.1038/ncomms10543

Edwards M, Richardson AJ (2004) Impact of climate change on marine pelagic phenology and trophic mismatch. Nature 430: 881-884. https://doi.org/10.1038/nature02808

Edwards M, Beaugrand G, Hays GC, Koslow JA, Richardson AJ (2010) Multi-decadal oceanic ecological datasets and their application in marine policy and management. Trends in Ecology and Evolution 25: 602-610. https://doi.org/10.1016/j.tree.2010.07.007

Field CB, Behrenfeld MJ, Randerson JT, Falkowski P (1998) Primary production of the biosphere: integrating terrestrial and oceanic components. Science 281: 237-240. https://doi. org/10.1126/science.281.5374.237

Finkel ZV, Beardall J, Flynn KJ, Quigg A, Rees TAV, Raven JA (2010) Phytoplankton in a changing world: cell size and elemental stoichiometry. Journal of Plankton Research 32: 119-137. https://doi.org/10.1093/plankt/fbp098

Giani M, Djakovac T, Degobbis D, Cozzi S, Solidoro C, Fonda Umani S (2012) Recent changes in the marine ecosystem of the northern Adriatic Sea. Estuarine, Coastal and Shelf Science 115: 1-13. https://doi.org/10.1016/j.ecss.2012.08.023

Godrijan J, Marić D, Tomažić I, Precali R, Pfannkuchen M (2013) Seasonal phytoplankton dynamics in the coastal waters of the north-eastern. Journal of Sea Research 77: 32-44. https://doi.org/10.1016/j.seares.2012.09.009

Godrijan J, Young JR, Marić Pfannkuchen D, Precali R, Pfannkuchen M (2018) Coastal zones as important habitats of coccolithophores: a study of species diversity, succession, and life-cycle phases. Limnology and Oceanography 63: 1692-1710. https://doi.org/10.1002/lno.10801

Grbec B, Matić F, Beg Paklar G, Morović M, Popović R, Vilibić I (2018) Long-term trends, variability and extremes of in situ sea surface temperature measured along the Eastern Adriatic Coast and its relationship to hemispheric processes. Pure and Applied Geophysics. https://doi.org/10.1007/s00024-018-1793-1

Guiry MD, Guiry GM (2018) AlgaeBase. Worldwide electronic publication, National University of Ireland, Galway. http://www.algaebase.org [Searched on 15 September 2018]

Hagino K, Okada H, Matsuoka H (2000) Spatial dynamics of coccolithophore assemblages in the equatorial western-central Pacific Ocean. Marine Micropaleontology 39: 53-57. https://doi.org/10.1016/S0377-8398(00)00014-1

Haidar AT, Thierstein HR (2001) Coccolithophore dynamics off Bermuda (N. Atlantic). Deep Sea Research Part II 48: 1925-1956. https://doi.org/10.1016/S0967-0645(00)00169-7

Hansen HP, Koroleff F (1999) Determination of nutrients. In: Grasshoff K, Kremling K, Ehrhardt M (Eds) Methods of Seawater Analysis. Wiley-VCH (Weinheim): 159-228. https://doi.org/10.1002/iroh.19850700232

Hays GC, Richardson AJ, Robinson C (2005) Climate change and marine plankton. Trends in Ecology and Evolution 20: 337-344. https://doi.org/10.1016/j.tree.2005.03.004

Henson SA, Sarmiento JL, Dunne JP, Bopp L, Lima I, Doney SC, John J, Beaulieu C (2010) Detection of anthropogenic climate change in satellite records of ocean chlorophyll and productivity. Biogeosciences 7: 621-640. https://doi.org/10.5194/bg-7-621-2010 
Hutchins DA, Fu F (2017) Microorganisms and ocean global change. Nature Microbiology 2: 17058. https://doi.org/10.1038/nmicrobiol.2017.58

Kaeriyama H, Katsuki E, Otsubo M, Yamada M, Ichimi K, Tada K, Harrison PJ (2011) Effects of temperature and irradiance on growth of strains belonging to seven Skeletonema species isolated from Dokai Bay, southern Japan. European Journal of Phycology 46: 113-124. https://doi.org/10.1080/09670262.2011.565128

Karatsolis B-T, Triantaphyllou MV, Dimiza MD, Malinverno E, Lagaria A, Mara P, Archontikis O, Psarra S (2017) Coccolithophore assemblage response to Black Sea water inflow into the north Aegean Sea (NE Mediterranean). Continental Shelf Research 149: 138-150. https://doi.org/10.1016/j.csr.2016.12.005

Kodama T, Wagawa T, Ohshimo S, Morimoto H, Iguchi N, Fukudome K-I, Goto T, Takahashi M, Yasuda T (2018) Improvement in recruitment of Japanese sardine with delays of the spring phytoplankton bloom in the Sea of Japan. Fisheries Oceanography 27: 289-301. https://doi.org/10.1111/fog. 12252

Kraus R, Supić N (2011) Impact of circulation on high phytoplankton blooms and fish catch in the northern Adriatic (1990-2004). Estuarine, Coastal and Shelf Science, 91: 198-210. https://doi.org/10.1016/j.ecss.2010.10.021

Latasa M, Scharek R, Vidal M, Vila-Reixach G, Gutiérrez-Rodríguez A, Emelianov M, Gasol JM (2010) Preferences of phytoplankton groups for waters of different trophic status in the northwestern Mediterranean Sea. Marine Ecology Progress Series 407: 27-42. https:// doi.org/10.3354/meps08559

Leblanc K, Quéguiner B, Diaz F, Cornet V, Michel-Rodriguez M, Durrieu de Madron X, Bowler C, Malviya S, Thyssen M, Grégori G, Rembauville M, Grosso O, Poulain J, de Vargas C, Pujo-Pay M, Conan P (2018) Nanoplanktonic diatoms are globally overlooked but play a role in spring blooms and carbon export. Nature Communications 9: 953. https:// doi.org/10.1038/s41467-018-03376-9

Legendre P, Anderson MJ (1999) Distance-based redundancy analysis: testing multispecies responses in multifactorial ecological experiments. Ecological Monographs 69: 1-24. https://doi.org/10.1890/0012-9615(1999)069[0001:DBRATM]2.0.CO;2

Lima FP, Wethey DS (2016) Three decades of high-resolution coastal sea surface temperatures reveal more than warming. Nature Communications 3: 704. https://doi.org/10.1038/ ncomms 1713

Ljubimir S, Jasprica N, Čalić M, Hrustić E, Dupčić Radić I, Car A (2017) Interannual (20092013) variability of winter-spring phytoplankton in the open South Adriatic Sea: effects of deep convection and lateral advection. Continental Shelf Research 143: 311-321. https:// doi.org/10.1016/j.csr.2017.05.007

Malačić V, Petelin B (2001) Regional studies: Gulf of Trieste. In: Cushman-Roisin B, Gačić M, Poulain P-M, Artegiani A (Eds) Physical Oceanography of the Adriatic Sea: Past, Present and Future. Kluwer Academic Publishers (Dordrecht): 167-181. https://doi. org/10.1007/978-94-015-9819-4_6

Marić D, Kraus R, Godrijan J, Supić N, Djakovac T, Precali R (2012) Phytoplankton response to climate and anthopogenic influences in the north-eastern Adriatic during the last four 
decades. Estuarine, Coastal and Shelf Science, 115: 98-112. https://doi.org/10.1016/j. ecss.2012.02.003

Marić Pfannkuchen D, Godrijan J, Smodlaka Tanković M, Baričević A, Kužat N, Djakovac T, Pustijanac E, Jahn R, Pfannkuchen M (2018) The ecology of one cosmopolitan, one newly introduced and one occasionally advected species from the genus Skeletonema in a highly structured ecosystem, the northern Adriatic. Microbial Ecology 75: 674-687. https://doi. org/10.1007/s00248-017-1069-9

Monti M, Minocci M, Milani L, Fonda Umani S (2012) Seasonal and interannual dynamics of microzooplankton abundances in the Gulf of Trieste (Northern Adriatic Sea). Estuarine, Coastal and Shelf Science, 115: 149-157. https://doi.org/10.1016/j.ecss.2012.03.032

Mozetić P, Solidoro C, Cossarini G, Socal G, Precali R, Francé J, Bianchi F, De Vittor C, Smodlaka N, Fonda Umani S (2010) Recent trends towards oligotrophication of the Northern Adriatic: evidence from chlorophyll $a$ time series. Estuaries and Coasts 33: 362-375. https://doi.org/10.1007/s12237-009-9191-7

Mozetić P, Francé J, Kogovšek T, Malej A (2012) Plankton trends and community changes in a coastal sea (northern Adriatic): bottom-up vs. top-down control in relation to environmental drivers. Estuarine, Coastal and Shelf Science, 115: 138-148. https://doi.org/10.1016/j. ecss.2012.02.009

Ninčević Gladan Ž, Marasović I, Grbec B, Skejić S, Bužančić M, Kušpilić G, Matijević S, Matić F (2010) Inter-decadal variability in phytoplankton community in the middle Adriatic (Kaštela Bay) in relation to the North Atlantic Oscillation. Estuaries and Coasts 33: 376-383. https://doi.org/10.1007/s12237-009-9223-3

Nishikawa T, Hori Y, Nagai S, Miyahara K, Nakamura Y, Harada K, Tanda M, Manabe T, Tada K (2010) Nutrient and phytoplankton dynamics in Harima-Nada, Eastern Seto Inland Sea, Japan during a 35-year period from 1973 to 2007. Estuaries and Coasts 33: 417-427. https://doi.org/10.1007/s12237-009-9198-0

Nunes S, Latasa M, Gasol JM, Estrada M (2018) Seasonal and interannual variability of phytoplankton community structure in a Mediterranean coastal site. Marine Ecology Progress Series, 592: 57-75. https://doi.org/10.3354/meps12493

Okada H, McIntyre A (1977) Modern coccolithophores of the Pacific and north Atlantic Oceans. Micropaleontology 23: 1-55. https://doi.org/10.2307/1485309

Poulain P-M, Cushman-Roisin B (2001) Circulation. In: Cushman-Roisin B, Gačić M, Poulain P-M, Artegiani A (Eds) Physical Oceanography of the Adriatic Sea. Past, Present and Future. Kluwer Academic Publishers (Dordrecht): 67-109. https://doi.org/10.1007/97894-015-9819-4_3

Querin S, Crise A, Deponte D, Solidoro C (2007) Numerical study of the role of wind forcing and freshwater buoyancy input on the circulation in a shallow embayment (Gulf of Trieste, northern Adriatic Sea). Journal of Geophysical Research 111: C03S16. https://doi. org/10.1029/2006JC003611

Ribera d'Alcalà M, Conversano F, Corato F, Licandro P, Mangoni O, Marino D, Mazzocchi MG, Modigh M, Montresor M, Nardella M, Saggiomo V, Sarno D, Zingone A (2004) Seasonal pattern in plankton communities in a pluriannual time series at a coastal Mediter- 
ranean site (Gulf of Naples): an attempt to discern recurrences and trends. Scientia Marina, 68: 65-83. https://doi.org/10.3989/scimar.2004.68s165

Rousseaux CS, Gregg WW (2015) Recent decadal trends in global phytoplankton composition. Global Biogeochemical Cycles 29: 1674-1688. https://doi.org/10.1002/2015GB005139 Salgado-Hernanz PM, Racault M-F, Font-Muñoz JS, Basterretxea G (2019) Trends in phytoplankton phenology in the Mediterranean Sea based on ocean-colour remote sensing. Remote Sensing of Environment, 221: 50-64. https://doi.org/10.1016/j.rse.2018.10.036

Sarno D, Kooistra WCHF, Medlin LK, Percopo I, Zingone A (2005) Diversity in the genus Skeletonema (Bacillariophyceae). II. An assessment of the taxonomy of S. costatum-like species, with the description of four new species. Journal of Phycology 41: 151-176. https:// doi.org/10.1111/j.1529-8817.2005.04067.x

Schlitzer R, 2015. Ocean Data View. http://odv.awi.de

Siegel S, Castellan NJ (1998) Non Parametric Statistics for the Behavioral Sciences, second ed. McGraw-Hill, New York, p. 399. https://doi.org/10.1177/014662168901300212

Skejić S, Arapov J, Kovačević V, Bužancić M, Bensi M, Giani M, Bakrač A, Mihanović H, Ninčević Gladan Ž, Urbini L, Grbec B (2018) Coccolithophore diversity in open waters of the middle Adriatic Sea in pre- and post-winter periods. Marine Micropaleontology 143: 30-45. https://doi.org/10.1016/j.marmicro.2018.07.006

Solidoro C, Bastianini M, Bandelj V, Codermatz R, Cossarini G, Melaku Canu D, Ravagnan E, Salon S, Trevisani S (2009) Current state, scales of variability, and trends of biogeochemical properties in the northern Adriatic Sea. Journal of Geophysical Research 114, C07S91. https://doi.org/10.1029/2008JC004838.

Šupraha L, Bosak S, Ljubešić Z, Olujić G, Horvat L, Viličić D (2011) The phytoplankton composition and spatial distribution in the north-eastern Adriatic Channel in autumn 2008. Acta Adriatica 52: 29-44.

Talaber I, Francé J, Mozetić P (2014) How phytoplankton physiology and community structure adjust to physical forcing in a coastal ecosystem. Phycologia 53: 74-85. https://doi. org/10.2216/13-196.1

Thackeray SJ, Henrys PA, Hemming D, Bell JR, Botham MS, Burthe S, Helaouet P, Johns DG, Jones ID, Leech DI, Mackay LB, Massimino D, Atkinson S, Bacon PJ, Brereton TM, Carvalho L, Clutton-Brock TH, Duck C, Edwards M, Elliott JM, Hall SJG, Harrington R, Pearce-Higgins JW, Høye TT, Kruuk LEB, Pemberton JM, Sparks TH, Thompson PM, White I, Winfield IJ, Wanless S (2016) Phenological sensitivity to climate across taxa and trophic levels. Nature 535: 241-247. https://doi.org/10.1038/nature 18608

Throndsen J (1978) Preservation and storage. In: Sournia A (Ed.), Phytoplankton Manual. UNESCO, Paris, 69-74.

Totti C, Civitarese G, Acri F, Barletta D, Candelari G, Paschini E, Solazzi A (2000) Seasonal variability of phytoplankton populations in the middle Adriatic sub-basin. Journal of Plankton Research 22: 1735-1756. https://doi.org/10.1093/plankt/22.9.1735

Utermöhl H (1958) Zur Vervollkommnung der quantitativen Phytoplankton-Methodik. Mitt. Int. Ver. Theor. Angew. Limnol. 9: 1-38. 
Viličić D, Djakovac T, Burić Z, Bosak S (2009) Composition and annual cycle of phytoplankton assemblages in the northern Adriatic Sea. Botanica Marina 52: 291-305. https://doi. org/10.1515/bot.2009.004

Viličić D, Kuzmic M, Tomažić I, Ljubešić Z, Bosak S, Precali R, Djakovac T, Marić D, Godrijan J (2013) Northern Adriatic phytoplankton response to short Po River discharge pulses during summer stratified conditions. Marine Ecology 34: 451-466. https://doi.org/10.1111/ maec. 12046

Zingone A, Totti C, Sarno D, Cabrini M, Caroppo C, Giacobbe MG, Lugliè A, Nuccio C, Socal G (2010) Fitoplancton: metodiche di analisi quali-quantitativa. In: Socal G, Buttino I, Cabrini M, Mangoni O, Penna A, Totti C (Eds.), Metodologie di studio del plancton marino. Manuali e Linee Guida 56/2010. ISPRA SIBM, Roma, 213-237. 